\title{
EL CONCEPTO DE SUJETO EN LA TEORÍA DE LA HISTORIA EN ESPAÑA.
}

\author{
por \\ Pedro José Chacón Delgado \\ Universidad del País Vasco (UPV-EHU)
}

RESUMEN: El objeto de este trabajo es el estudio de los diferentes conceptos de Hombre (entendido aquí como sujeto en la Teoría de la Historia) que se dieron en España durante el siglo XIX y que contribuyeran de modo decisivo a configurar la tipología de los bistoriadores del periodo.

La Historia de la Historiografia forma parte de la Historia de la Cultura (caracterizada por lo que boy se conoce como "el retorno del sujets") y nos ofrece un depósito documental donde el relato de los bechos del pasado viene condicionado por las premisas teóricas y las circunstancias socio-bistóricas desde las que se elaboraron las obras de Historia en cada época.

PALABRAS Clave: Historiografía española. Siglo XIX. Historiadores. Filosofía de la Historia. Romanticismo. Historicismo. Krausismo. Volksgeist. Völkerpsychologie.

ABSTRACT: The subject of this paper is the study of the different concepts of Man (considered as the agent in the Theory of History) that were used in Spain during the nineteentb century and which contributed in a decisive manner to configure a typology of bistorians in that period.

The History of Historiograpby is a part of the History of Culture (characterised today by the importance of the buman agent) and provides a documentary deposit where the narrative of past facts is conditioned by the intellectual theories and socio-bistorical circumstances that are the basis of bistory books.

KEY wORDS: Spanish Historiography. Nineteenth century. Historians. Philosophy of History. Romanticism. Historicism. Krausism. Volksgeist. Völkerpsychologie. 
«Se sospecha del tipo de hombre que fabrica esos eruditos productos; se cree, no sé si con justicia, que tienen almas retrasadas, almas de cronistas, que son burócratas adscritos a expedientear el pasado. En suma, mandarines. (...) Y no puede desconocerse que hay una desproporción escandalosa entre la masa enorme de labor historiográfica ejecutada durante un siglo y la calidad de los resultados. Yo creo firmemente que los historiadores no tienen perdón de Dios»!.

La figura intelectual de Ortega es tan desproporcionada respecto a lo que se dió en España hasta entonces en la cuestión de las relaciones entre Filosofía e Historia, que todo este trabajo que ahora comienza (circunscrito al siglo XIX, que es precisamente al que se refiere Ortega en su cita) no podría aspirar a ser más que una pequeña introducción para abordar su pensamiento historiológico con cierta perspectiva. Traer a Ortega a colación aquí, por tanto, lo considero necesario como horizonte intelectual de referencia en un trabajo dedicado a analizar las teorías filosóficas (centradas en el concepto de sujeto) que sirvieron de fundamento a la elaboración de la Historia en España.

Sabido es que en nuestra lengua el término Historia sirve tanto para denominar al pasado en cuanto tal como también al relato de dicho pasado. La Historia como "res gestae" y como "Historia rerum gestarum" ${ }^{2}$. Sin entrar a celebrar lo afortunado de esta anfibología o a rechazarla buscando términos discriminatorios de manera perentoria ${ }^{3}$, lo cierto es que basta con pensar en cada uno de los dos significados de la misma para comprender que, de igual manera, hay un sujeto que la protagoniza, y que según la época de la Historia de la Historiografia a que nos refiramos será un rey o un noble o el pueblo en su totalidad o sus héroes o una clase social o las estadísticas de población; $\mathrm{y}$ hay también un sujeto que elabora discurso histórico, el historiador mismo, que deberá ser una persona con unos fundamentos diferentes acerca de la realidad que relata, de la misma realidad que él vive, de su lugar en ella en cada momento. Este último es precisamente nuestro objeto de estudio en este trabajo: el historiador entendido como sujeto que elabora Historiografía y en el que confluirán, de manera inevitable, las dos maneras de ver el pasado, como res gestae y como relato del mismo, y que le harán elegir un periodo, unos hechos, un ámbito geográfico, unos personajes y no otros, y también explicar lo que pasó conforme a unos valores u otros. Argumentar esta naturaleza dicotómica de enfrentarse al pasado requeriría un trabajo completo aparte, por lo que tan sólo me limitaré a recordar aquí que Ranke, el principal valedor de la Historia como relato de los hechos tal como sucedieron, y Droysen, el padre de la hermenéutica histórica, son estrictamente coetáneos ${ }^{4}$.

\footnotetext{
1 ORTega y Gasset, José: "La 'Filosofía de la Historia' de Hegel y la historiología” (1928), Obras Completas, (12 vols.), Madrid, Alianza Editorial, 1983, Vol. IV, p. 524.

2 Ver Benavides LUCAS, Manuel: Filosofia de la Historia, Madrid, Síntesis, 1994, capítulo 1.

3 Ver ARóstegui, Julio: La investigación histórica; teoría y métado, Madrid, Crítica, 1995, pp. 20ss.

"Ver RuIz TORRES, Pedro: "Historia filosófica e historia erudita en los siglos XVIII y XIX", en Francisco M. Gimeno Blay (edit.): Erudición y discurso bistórico: Las instituciones europeas (ss. XVII-
} 
En el ámbito hispánico podemos referirnos, para ilustrar estos planteamientos, que constituyen el núcleo de la Teoría de la Historia, a José Antonio Maravalls. En la Historia como pasado «los hechos humanos son siempre hechos envueltos en un pensamiento, son hechos que van tejidos siempre con ideas, sentimientos, aspiraciones, voliciones, etc., desprendidos de los cuales aquéllos no es que resulten amputados, sino que como hechos humanos no existen". Del mismo modo que la Historia como pasado requiere su fundamento en la teoria que hay detrás de ese pasado, la Historia como narración de lo pasado debe también responder al «esquema completo de la ciencia», conformado por «a) un sistema de categorías aplicables a la realidad; b) un conjunto de materiales en los que ésta se nos ofrece; c) una articulación lógica de interpretaciones con las que damos cuenta racionalmente de esa realidad». La conexión necesaria entre ambos tipos de Historia y ambas maneras de concebirlas pasa necesariamente por el concepto de sujeto: «la estructura es de los hechos, surge de su articulación; pero sin la observación de un sujeto no se da». Autores contemporáneos en el ámbito hispánico corroboran, por otra parte, la necesidad de aunar ambos significados del término Historia en una misma estrategia de investigación. Así, Miguel Artola lo dejó apuntado en un artículo temprano suyo ${ }^{6} \mathrm{y}$, más recientemente, José Carlos Bermejo Barrera lo viene sosteniendo en toda su obra publicada al respecto $\%$

Algo específico de las fuentes disponibles en una investigación de este tipo obliga a reconocer una realidad de partida: que no podemos esperar de las obras de los historiadores españoles del XIX que éstos nos digan qué mundo teórico era el que habitaba sus cabezas cuando las escribían. Esto no nos lo di-

$X I X)$, (Seminari Internacional d'Estudis sobre la Cultura Escrita, 23-26 de Noviembre de 1992), Valencia, Universitat de València, 1993, pp. 13-33; «La historia como concepto histórico: histocia erudita, historia filosofica e historia científica en los siglos XVIII y XIX», en Studia HistoricaHistoria Contemporánea, Vol. X-XI (1992-93), pp. 149-162; y "Los discursos del método histórico", Ayer, $\mathrm{n}^{\circ}$ 12, 1993, pp. 47-77; de Pasamar Aizuris, Gonzalo: «La invención del método histórico y la historia metódica en el siglo XIX», en Historia Contemporánea (U.P.V.), $\mathrm{n}^{\circ} 11,1994$, pp. 183-213.

"Ver, para las citas que siguen: Maravall, José Antonio: «Problemas de la historia del pensamiento" (1955) en Menéndez Pidal y la bistoria del pensamiento, Madrid, Arión, 1960, p. 18; «Menéndez Pidal y la renovación de la historiografía» (1959) en Menéndez Pidal..., op. cit., p. 93; Teoría del Saber Hist6rico, $3^{\text {a }}$. edic. amp., Madrid, Revista de Occidente, 1967 (1958), p. 193.

'ARTola, Miguel: "En torno al concepto de Historia», en Revista de Estudios Politicor, 99, 1958, pp. 145-183: «El divorcio existente entre filósofos e historiadores es responsable de manera fundamental de la falta de una visión completiva de la historia. La entrega de la filosofía de la historia a los filósofos, y lo que es peor, la falta de consideración para sus especulaciones (...) es causa de la inautenticidad de una gran parte de la investigación histórica, que se manifiesta de manera flagrante en la falta de interés que inspira, falta de interés que no puede achacarse sino al propio historiadors (p. 177).

7 Véanse sus obras: Psicaanálisis del conocimiento bistorico, 1983; El Final de la Historia: Ensayos de Historia Térica, 1987; Replanteamiento de la Historia: Ensayos de Historia Térica II, 1989; Fundamentación logica de la Historia: Introduction a la Historia Teórica, 1991; Entre Historia y Filosofla, 1994; todas ellas publicadas por Akal, Madrid. 
cen o si intentan decírnoslo no entendemos aún las claves de que se valen para hacérnoslo llegar. Y ello sucede por una razón fundamental: el carácter subsidiario de la Historiografía española del siglo XIX respecto de las demás disciplinas intelectuales, y de los mismos historiadores en cuanto ejercen de tales. Para ilustrar esta realidad bastaría con acudir a un personaje tan representativo de la Historiografía española del período y de los historiadores entendidos como eruditos, Marcelino Menéndez Pelayo, para quien, mientras esperamos el "advenimiento" del historiador genial, es obligación de los contemporáneos perseverar en una suerte de labor investigadora previa a su llegada ${ }^{8}$. $\mathrm{O}$, desde la vertiente opuesta del panorama intelectual español (ambas se enfrentarán en la famosa polémica sobre la ciencia española en plena Restauración), podemos acudir a Gumersindo de Azcárate 9 , para comprobar cómo, respecto de la Sociología (entonces naciente) o de la misma Filosofía de la Historia, la Historia quedará como subsidiaria, mera aportadora de documentación más o menos tratada o expurgada. Pero de otro modo, la Historia no resultará tan vapuleada. Para Cánovas del Castillo servirá nada menos que de fundamento de la existencia de la nación española, de acuerdo con su principio de «constitución interna». Esto ya era algo. Porque frente a los reaccionarios, que siempre apelaban al catolicismo como primer fundamento de la nación, él recurrirá a la Historia, con lo cual, de alguna forma, nos deja la puerta abierta para poder pensar que todo podría haber sucedido de otro $\operatorname{modo}^{10}$. Y, en fin, Rafael Altamira comprenderá, ya con el cambio de siglo, que la Historia, como Historiografía, es el principal agente civilizador y, de paso, nacionalizador, del país, y procurará, desde la administración de la enseñanza, elevar su estatus científico por encima de su carácter literario y darle la importancia pedagógica que siempre tuvo pero que hasta entonces no se quiso, no se pudo o no se supo aprove-

8 "... así nos es lícito soñar para muy remotas edades con el advenimiento de un histociador aun más grande que Tácico y que Macaulay, el cual haga la hiscoria por la historia, y con alta impersonalidad, y sin más pasión que la de la verdad y la hermosura, reteja y desenrolle la inmensa tela de la vida. Pero antes de que el historiador perfecto llegue, es preciso que se cumpla la obra de investigación en que nuestro siglo está empeñado", en: Menéndez Pelayo, Marcelino: «La Historia considerada como arte bella", en Discursas leidos ante la Real Academia de la Historia en la recepción publica de __ el 13 de mayo de 1883, Madrid, Imprenta Central a cargo de Vicrot Saiz, 1883, pp. 38-39.

Sr. D.

"De AzCárate, Gumersindo: «Concepto de la Sociología” (Discurso de recepción del Ilmo. Mayo de 1891), en Revista de Estudios e Investigaciones Sociologicas, $n^{\circ}$ 56, 1991, pp. 245-273. El papel reservado aquí a la Historia se vería fundamentado en otro discurso posterior: «Carácter científico de la Historian (parte doctrinal del discurso de ingreso de Gumersindo de Azcárate en la Real Academia de la Historia, 3 de abril de 1910), en Boletin de la Institución Libre de Enseñanza, XXXIV, 1910, pp. 125-128, 153-160, 178-192.

Io Ver DARDÉ, Carlos: «Cánovas y el nacionalismo liberal español», en Guillermo Gortázar (edit.): Nación y Estado en la España liberal, Madrid, Noesis, 1994, pp. 209-238.

Hispania, LX/1, núm. 204 (2000) 255-287 
char, que de todo hubo"1. Decisiva como explicación de la realidad política y social, subsidiaria en el currículum de los saberes de cualquier protagonista social del siglo: todos son historiadores aficionados, necesitan la Historia pero para otra cosa: para la política, para la literatura, para el desarrollo de la ciencia social en ciernes al final del período. Cánovas, Menéndez Pelayo, Azcárate y Altamira serán autores de finales de siglo. Para entonces la Historiografía en España se ha ido secularizando, profesionalizando, queriéndose, a la vez, equiparar - en un proceloso y a la postre fútil intento- - con las ciencias físiconaturales, convirtiéndose en educadora cívica y patriótica.

La necesidad de considerar todo el período del XIX en la Historia de la Historiografía en España se hace necesario en un trabajo de este tipo puesto que se trata de lo que podemos denominar un "período de inteligibilidad». La Historia, durante el mismo, se verá protagonizada por un historiador que principalmente será otra cosa antes que historiador: político, literato ${ }^{12}$. Para comprender esto tendríamos que realizar un estudio acerca del significado de la Historiografia en todo el período, formando parte de las Bellas Letras prácticamente hasta final de siglo, y del concepto mismo de Historia de España también, sirviendo para fundamentar teóricamente, tan sólo con la apelación a la palabra Historia, las ideologías políticas en liza ${ }^{13}$. La Historiografía ocupará un lugar secundario en la escala del saber. La Historia misma, como parte de la Filosofía, seguirá sirviendo de fundamento a la visión cristiana del hombre en su relación con Dios o experimentará una laicización progresiva, con la introducción de leyes y teorías que la querrán explicar sin apelar a ningún ente trascendente ${ }^{14}$.

Lo que se dirime en el fondo de todas estas realidades es la idea de hombre que se tiene durante todo el período del siglo XIX en España. Hombre o mujer, persona en definitiva. De esta instancia es de la que queremos partir al considerar el concepto de sujeto y su relación con la Teoría de la Historia, porque el individuo es la instancia previa e imprescindible para la inteligibilidad de lo social y de lo histórico, como quien lo realiza y como quien lo piensa y teoriza. Partiendo de la base de que la Historia no necesita indagar en su condición o no de ciencia (social) para justificar su validez intelectual, tampoco por ello

${ }_{11}$ Ver P. BoYD, Carolin: Historia Patria, Politics, History and National ldentity in Spain, $1875-$ 1975, Princeton, Princeton University Press, 1997, capítulo 5: «History Recovered: Rafael Altamira and National Regeneration".

12 CIRUjano MaríN, Paloma: «Aproximación sociológica al panorama historiográfico español, 1844-1874", en Estudios de Historia de España. Homenaje a Manuel Tuñón de Lara, Madrid, U.I.M.P., 1981, T. Il, pp. 697-711.

${ }^{13}$ JIMÉNEZ DíEZ, José Antonio: «Ideología y política en la historiografía española de 1844 a 1874", pP. 679-695;y $\mathbf{M}^{\mathrm{a}}$. Teresa ElORRIAGA PLANES: «Evolución temática de la historiografia española de 1844 a 1874, pp. 713-722, ambos trabajos en Estudios de Historia de España. Homenaje a Manuel Tuñón de Lara, op. cit.

if Para explicar este proceso sigue siendo imprescindible la obra de Diego NúÑEz RuIZ: La mentalidad positiva en España, Madrid, Túcar, 1975. 
cabe quedarse en su carácter de mero discurso histórico, en su narratividad. Pero en lo que no estoy de acuerdo es en que para colocar a la Historia entre las demás ciencias sociales y buscarle un papel «hontoso" como agente explicador de todo lo que tenga que ver con el cambio, con el transcurso del tiempo, se la haga protagonizar por «lo social»15. El protagonista debe de ser siempre el individuo, como motor de pensamiento y de cambio. En Historia de la Historiografía esto no creo que admita mucha discusión: sólo podemos hablar de historiadores individualmente considerados $y$, a partir de ellos, si queremos, podemos hablar de corrientes historiográficas y de instituciones creadas por ellos y para ellos. Pero es que en la Historia en general, como explicación de la realidad pasada, en toda su amplitud considerada, el individuo es siempre la primera y la última referencia, bien por su potencialidad creadora, bien por su seguidismo partidista, bien por su condición de minoría o de masa. Lo social actuará sobre él, le influirá, conformará una explicación contextual, condicionadora, anuladora incluso de su identidad, pero siempre hablaremos de lo social por referencia a ese individuo insoslayable ${ }^{16}$.

Lo que se está dirimiendo aquí, en definitiva, es la constitución de la Historia como relato del pasado, tal como la conocemos hoy, profesionalizada en la Universidad e inserta, así, en una estructura docente e investigadora. Sentado el principio de que la Historia como pasado está ahí, a nuestra merced, siempre

15 Es lo que propone, desde la sociología, Santos Juliá: Historia social / saciología bistórica, Madrid, Siglo XXI, 1989, 98 págs. Pero también, desde la historiografía, Julio ArósTEguI: La invertigación bistórica: teoria y método, op. cit.

16 Ver GUERRA, François-Xavier: «El renacer de la historia política: razones y propuestas», en ANDRÉs-Gallego, José (dir.): New History, Nouvelle Histoire, Hacia una nueva Historia, Actas de los Cursos de Verano en El Escorial, Madrid, Universidad Complutense, 1992, pp. 221-244. Es, sobre todo, el concepto de los «actores reales" y la búsqueda de los mismos por parte de la "Nueva Historia Política», donde viene a significar la clave de esta disciplina. Buscar los «actores reales» es un ejercicio de desvelamiento de abstracciones que hasta ahora han resultado muy cómodas en Historia Política: individuos que se erigen en representantes de toda una clase social, de una nación, de un grupo político; esas mismas entidades colectivas entendidas como entidades abstractas, con vida propia, cuando lo que hay que hacer es analizar los individuos que las componen, la forma de actuar en grupo, las dependencias, jerarquías, dinámicas de poder que se establecen dentro de ellos y que pueden explicar el equilibrio, inestable siempre, con que se mueven; la existencia de individuos significativos en cualquier período histórico, pero siempre entendidos dentro de una red de condicionamientos y servidumbres. Este es un ejercicio que ya empezaron a practicar los primeros sociólogos y psicólogos sociales del XIX y que en España comprobaremos cómo, dentro de lo historiográfico, fue Rafael Altamira quien lo empleó con mayor seriedad.

La obra recientemente publicada de Narciso PIZArRo (Tratado de metodologia de las Ciencias $S_{0-}$ ciales, Madrid, Siglo XXI, 1998), aunque en una dimensión más completa y profunda que el arrículo anterior, también nos sicúa en la necesidad de abordar el estudio de las ciencias sociales desde el individuo, para después analizar la interacción microsociológica, y sólo entonces llegar a la consideración de las estructuras sociales. Mi propuesta teórico-historiográfica, por tanto, como se irá viendo a lo largo de este trabajo, es decididamente individualista, sin negar la presencia de lo social, pero situándola en su debida dimensión.

Hispania, LX/1, núm. 204 (2000) 255-287 
dispuesta a ser considerada a la medida de nuestras necesidades o urgencias del presente, la Historia como relato de los hechos del pasado es algo histórico propiamente dicho, documentado, y es, en efecto, un producto diferenciable sustantivamente en función precisamente de quién sea el sujeto que lo produce: de cómo se considere a sí mismo, respecto de qué instancias se defina, de qué autoridades se reclame deudor, qué concepto tenga del pasado y qué busque en la indagación del mismo. Y es precisamente en la Europa de la llustración donde se inicia una transformación sustancial del concepto de sujeto y, con él -entre otros productos de su ingenio-, de la Historia como relato que a partir de entonces elabore.

Podríamos abordar de muchas maneras el estudio del concepto de sujeto en relación con su "producción" de Historia: bien de modo cronológico, bien estableciendo polos de contraste según las diferentes teorías que lo han considerado. Lo cierto es que necesitaríamos una serie de ideas previas, globales, para situar nuestro objeto de estudio. Todo el siglo XIX en España se podría articular en torno a dos novedades de fondo: la construcción del Estado-nación burgués (que en España no deja de ser una propuesta fundada en un modelo mezcla del inglés y del francés ante cuyo espejo todo parecerán debilidades o desencajes, sin reparar en la especificidad de lo español ${ }^{17}$, constituido por una rémora insalvable de Antiguo Régimen y un acoso de las propuestas sociales y culturales específicas del XIX y derivadas de la Revolución Industrial peculiar del país) y por un proceso lento pero constante de secularización del pensamiento y de la misma sociedad. Vamos a ver cómo ambos procesos son, en sus ideales y en sus dificultades, como no podía ser de otro modo, determinantes para nuestro objeto de estudio.

La construcción del liberalismo político, basado en la preeminencia del individuo en lo social, tiene su antecedente inmediato en la Ilustración. Según este movimiento intelectual, será desde el individuo, mediante el desenvolvimiento de todas sus potencialidades, que se podrá llevar a cabo la liberalización de las ataduras que tradicionalmente han venido oprimiendo la consecución de su felicidad, término éste al que los pbilosopbes apelarán sin rubor. La Historiografia formaba parte entonces, ya está dicho, del conjunto de la Literatura o Bellas Letras. Y la Historia se consideraba también filosóficamente (sobre todo eso: filosóficamente) hasta el punto de olvidarse de guardar fidelidad a los hechos: precisamente era éste el tradicional reproche de los eruditos a los philosophes. Pero en ambos casos, como Historiografía y como Historia, se la hacía depender, junto con los demás saberes, del sujeto individualmente considerado ${ }^{18}$. Y así es como pasará al XIX, con las transformaciones que veremos.

\footnotetext{
17 Ver Pérez Garzón, Juan Sisinio: «La nación, sujeto y objeto del estado liberal español» en Historia Contemporánea, U.P.V., 17, 1998, pp. 119-138.

18 «Si el acercamiento filosófico al cronco subjetivo del árbol del saber había dado a la literatura \{historiografía incluida\} un lugar psicológico como fenómeno relativo del conocimiento individual, de la misma manera el estudio igualmente filosófico de la historia y de la sociedad conforme al
} 
Por lo que respecta a la secularización, este proceso es paralelo al considerado en el ámbito social y político. Significará «la negación de todo lo que no sea el propio ser del hombre", "la suficiencia de la persona para hacerse a sí misma oriunda del éxito de sus fuerzas para vivir» ${ }^{19}$. Las repercusiones de este proceso serán inmensas. A nuestros efectos significará, nada menos, que la quiebra del principio providencialista en Historia. Es lo que Menéndez Pelayo denominará la «teoría de lo Inmanente» ${ }^{20}$. Para cuando empiezan a formularse estos planteamientos la única teoría global de lo humano es la procedente de la Iglesia católica en España, que ha dominado el saber durante siglos, cerrada con una obcecación legendaria a toda influencia procedente de donde fuera, que alterara su esquema y visión del hombre y la sociedad, panorama hispánico donde la creencia dominante (tanto en el sentido religioso como en el sociológico orteguiano) consideraba a la persona como incapaz de razonar por sí misma sin el auxilio divino. Conforme con este principio: «la razón individual es inferior a la 'verdad' revelada y tradicional»; sus principales teóricos (que, paradójicamente para una teoría tan castiza, también son foráneos), De Bonald y De Maistre, «sostienen el origen divino de la sociedad, la superioridad de la sociedad sobre el individuo y la base divina de la autoridad» ${ }^{21}$. Es, por tanto, la sociedad (=la nación), cuyo origen y fundamento se da por divino (la traslación de este principio a la Historia será la leyenda de Túbal para explicar los orígenes bíblicos de la nación española, algo muy típico de la historiografía tradicionalista de todo el siglo), y como depositaria de la tradición y base de toda autoridad, la encargada de conformar al individuo según los patrones de la verdad revelada. Para los que no «comulgaran" con este principio era, pues, inaplazable la necesidad de fundar una teoría del hombre que explicara la sociedad y la historia sin más recursos que los que el propio hombre obtuviera de sí mismo.

\footnotetext{
método de observación y análisis hizo que fuese pensada como fenómeno igualmente inserto en un conjunto de 'faits historiques'. De este conjunto formaba parte junto con la religión, las costurnbres, el gobierno, las leyes, la moral o el comercio, todos los cuales fueron concebidos no por su singularidad y objetividad, sino por sus relaciones entre sí y su dependencia, como 'cosas humanas', de la 'fuerza racional' del sujeto. Fue en ésta en la que se buscó siempre el principio lógico, la unidad, el punto de apoyo del sistema de la historian: en Garrido Palazón, Manuel: La Filosofía de las Bellas Letras y la Historia Literaria en España (1777-1844), Campus Universitario de Almería, Instituto de Estudios Almerienses, 1992, pp. 97-8.

19 Ver Alvarez TuRUenzo, Saturnino: «Génesis y manifestación del ateísmo en el pensamiento contemporáneo", en Revista de Filosofia, n's 96-99, 1966, pp. 155-194, las citas en 161 y 160 respec.

20 \&... la teoría de lo Inmanente, punto de arranque para la afirmación del derecho de to humano, y para la negación de lo sobrenatural en lo divino", en: MENÉnDEz PELAYO, Marcelino: Historia de los beterodoxos españoles (edic. de Enrique Sánchez Reyes), Tomo VI, «Heterodoxia en el siglo XIX (aparece como tomo 40 de la Edicion Nacional de las Obras Complesas de Marcelino Menéndez Pelayo, dirigida por Angel González Palencia, C.S.I.C, 1948), Santander, Aldus, 1948, p. 468.

2t Ver RoDríguEZ, José Luis: «Los orígenes del pensamiento reaccionario español», en Boletín de la Real Academia de la Historia, Tomo CXC, 1993, pp. 31-119, espec., pp. 33ss.
} 
Frente a la «pureza» de ambos posicionamientos, liberal y reaccionario, el grueso de los historiadores españoles del XIX se moverán conforme a los principios de lo que se ha venido en denominar moderantismo o doctrinarismo, en lo que quería ser precisamente una esforzada amalgama o simbiosis de aquellas dos teorías por principio incomunicables entre sí. Según esta corriente ideológi$\mathrm{ca}$, armazón fundamental de la política y las ideas en este período ${ }^{22}$, se va a constituir una Historia general caracterizada por su providencialismo y por el par político doctrinario de las Cortes con el Rey, que interpretará la historia política e institucional de España conforme con ese patrón. Aquí no interesa, de momento (se hará en seguida), entrar en el relato de esta Historiografía. Interesa, eso sí, conocer qué concepto de sujeto está detrás de ella. Para esta tarea no tenemos por más que recurrir a las ideas que en los demás campos de la cultura resultan decisivas entonces.

Toda la cultura del XIX está imbuida de Romanticismo. El problema, en lo que respecta a España, es la identificación alternativa y excluyente que se hace del mismo, por una parte, con el Liberalismo y por otra con el Historicismo y que afectará decisivamente al concepto de sujeto que se derive de ello.

La tesis de que el Romanticismo es igual a Liberalismo asocia éste con la lucha en España contra la reacción y por el afianzamiento de los principios del doceañismo y de los derechos del hombre promulgados entonces. Desde luego que es posible sostener y fundamentar los orígenes del sujeto romántico-de sus ansias de libertad y de no sometimiento a nadie, de su anhelo de fusión con el universo entero sin intermediarios de por medio--, en ese sujeto ilustrado que cree firmemente que con su sola razón puede descubrir todo lo necesario para vivir. Esta conexión en España se daría a través de la filosofía sensista de las escuelas salmantina y sevillana y, con la influencia singular de un Destutt de Tracy, produciría un sujeto romántico donde el empirismo sensista dieciochesco, en lugar de expandirse a la indagación de lo exterior fundamentando así el estudio de la naturaleza y el desarrollo de las ciencias naturales, se traduciría, en el caso español, en el conocimiento de sus propios sentimientos, de su vida interior, de la actividad de su alma, de carácter psicológico, íntimo, moral, ajeno a la comprensión de un mundo exterior que se antoja caótico, ajeno, inaprensible ${ }^{23}$. Esta raigambre ilustrada y el carácter liberal de nuestro Romanticismo se defiende hoy de una manera apasionada en las obras de Diego Martínez Torrón ${ }^{24}$, basándose en autores como Quintana 0 , singularmente, Lista. Para Martínez Torrón todo surge de los philosopbes, tanto el liberalismo como el

\footnotetext{
22 Ver DíEZ DEL CORRAL, Luis: El liberalismo doctrinario, $3^{\text {a }}$ edic., Madrid, Instituto de Estudios Políticos, 1973 (1945).

23 Ver SÁNCHEZ BLANCO, Francisco: «La filosofía sensista y el sueño de la razón romántica», en Cuadernos Hispanoamericanos, $n^{\circ} 381,1982$, pp. 509-521.

2i Ver MARTíneZ TORRón, Diego: El alba del romanticismo español (espec. pp. 19-20, 34-5 y 73) y, sobre todo, para los efeccos de este trabajo, Ideología y literatura en Alberto Lista; ambas en Sevilla, Alfar, 1993.
} 
espíritu del pueblo. La alternativa a este planteamiento, como decíamos, es la identificación del Romanticismo con el Historicismo, entendido éste como la expresión cultural de la línea más tradicional del pensamiento político español: aquél que reivindica las esencias nacionales basadas en la religión católica y en un concepto de Estado avalado por la Historia y sus hitos principales interpretados según este ideario.

Frente a ambas identificaciones la crítica literaria actual busca la comprensión de todo el proceso, integrando los tres elementos en liza (Romanticismo, Liberalismo, Historicismo) a la vista de la realidad coetánea del Romanticismo europeo. Esta problemática, reservada aparentemente a la Filología, no puede ser ignorada aquí puesto que, como ya se ha dicho, los historiadores son entendidos, durante prácticamente todo el siglo, como cultivadores de un género didáctico dentro de las Bellas Letras. De ahí que quepa fijarse en cómo actualmente es defendida una interpretación del Romanticismo en España como un caso particular del genuino romanticismo europeo (el llamado «alto romanticismo", con el yo pujante en el centro de todas sus consideraciones, en su religiosidad exaltada y heterodoxa, en su apelación a la Historia como progreso y liberación pero también como búsqueda de lo original, de la diferenciación), que en España no se daría plenamente, cuando menos, hasta la "Gloriosa» del $68 \mathrm{y}$, de manera definitiva, con la generación del $98^{25}$. Lo que nos interesa discernir, por tanto, es qué tipo de Romanticismo se da entonces en España hasta la revolución de 1868 . Y lo que nos encontramos ${ }^{26}$ es un Romanticismo específico español dividido en dos fases, una denominada de «romanticismo histórico», que iría de 1814 a 1844 , y otra posterior de «nacional-romanticismo», de 1844 a 1868.

La primera fase del Romanticismo en España seguirá un criterio, ya expresado en su denominación, de "un romanticismo histórico: 1) del corazón, de las sensaciones y el sentimiento; 2) que implicaba la liberación de las reglas neoclásicas», pero, además, ahora se le añade un romanticismo «3) de carácter retrospectivo, patriótico y, en definitiva, ahistórico (...), y 4) que llevaba en sí una peculiar catacresis del historicismo romántico herderiano como principio estructurador», que aportaba una singular incapacidad al moderantismo para distinguir entre pasado y presente, lo cual coadyuvaba a fundamentar sus intereses ideológicos. Aquí es donde aparece nuestro interés por esta primera fase. Un singular autor como el ya mencionado Alberto Lista, educador de toda una generación romántica, la de Espronceda, Ochoa, Bécquer, etc., pondrá todo su

25 Es la propuesta de Juan Luis ALBORG en su Historia de la literatura española, Vol. IV, Madrid, Gredos, 1980 , p. 69 , pero que no desarrolla en este volumen, últirno publicado hasta ahora: ver SILVER, Philip W.: Ruina y Restitución: Reinterpretación del Romanticismo en España, Madrid, Cátedra, 1996, p. 108, nota 83.

${ }^{26}$ de la mano de un autor como el ya citado Philip W. Silver, que nos ofrece la última revisión de estos problemas en Ruina y Restitucion..., op. cit. pp. 34, 36, 37-39 y 110, donde el autor explicita las denominaciones y límites cronológicos de las das fases del romanticismo que él distingue.

Hispania, LX/1, núm. 204 (2000) 255-287 
empeño en format una élite de «sabios» que serían los encargados de crear una «opinión pública» frente a la que el pueblo, siempre excluido de cualquier participación política, actuaría como recipiente pasivo. En este periodo de «tomanticismo histórico" aparecen también las Historias de la Civilización Española de Eugenio de Tapia (1840), de Fermín Gonzalo Morón (1841-46, basada en los cursos impartidos por el autor en $1840-41$ ) y de Juan Cortada (1845) ${ }^{27}$, entre otros, en la estela de las obras de Guizot sobre Historia de la Civilización en Europa y en Francia ${ }^{28}$. Estas obras constituirían para nosotros la supervivencia del concepto liberal de raíz ilustrada (ahora según el «formato» liberal doctrinario) en esta fase del romanticismo que estamos analizando, frente a las Historias generales de la fase inmediatamente posterior. El modelo de historiografía que quieren seguir es aquél cuyo objeto son todas las actividades en las que se desenvuelve el espíritu burgués, no solamente las políticas, como seguirá siendo Io usual en la Historiografía isabelina. Sólo que el contenido del concepto de civilización irá perdiendo progresivamente su pretendido carácter universalizador (que no deja de ser eurocéntrico) para pasar a concretarse cada vez más según los principios diferenciadores que los propios ilustrados ya empezaron a bosquejar: baste citar, para ello, la obra de Voltaire, el padre de la Historia civil y laica: Essai sur les moeurs et l'esprit des nations (1756), donde Ciriaco Morón Arroyo, en reciente diálogo personal con él ${ }^{29}$, hace residir el verdadero origen del concepto de Volksgeist (sólo que, cabría matizar, cuidando siempre de desactivar esa carga esencialista que lo caracteriza, anuladora de la individualidad liberal). Mi hipótesis al respecto, que desarrollaré más adelante, es que este concepto, especialmente en la siguiente fase del romanticismo, la nacionalromántica, convivirá demasiado estrechamente -era algo inevitable-con el concepto esencialista del reaccionarismo español, que vimos supra, con su componente divinizador de la sociedad (de su origen, fundamento y autoridad), como para poder reivindicar a la vez el espíritu liberal del que surge. Será cuando se desprenda, a partir de la revolución del 68 y de los krausistas, de ese

${ }^{27}$ A quien Josep FonTANA considera «tal vez el más coherente desde un punto de vista metodológico de los historiadores españoles de aquel tiempo», en: «La historiografia española del siglo XIX: un siglo de renovación entre dos rupturas", en Santiago Castillo (coord.): La Historia Social en España, Actualidad y perspectivas. Actas del ler. Congreso de la Asociación de Historia social, Zaragoza, Septiembre de 1990, Madrid, Siglo XXI, 1991, pp. 325-335; la cita en p. 326.

${ }_{28}$ Ver FERNÁNDEZ SEBASTIAN, Javier: «La recepción en España de la Histoire de la Civilisation de Guizot", en Jean-René Aymes y Javier Fernández Sebastián (edits.): La imagen de Francia en España (1808-1850), Leioa, Servicio de Publicaciones de la U.P.V., 1997, pp. 127-149.

29 Tal «diálogo personal» se efectuó vía módem y el aspecto ahora aludido consca en un e-mail del profesor Morón-Arroyo (<cma6@cornell.edu>) que recibi con fecha 17-XII-1998: «A mí me parece que el Volksgeist es de origen absolutamente liberal. Tanto que es traducción de Volraire: 'Esprit des nations' -Ortega lo notó ya hace muchos años-... iCuál fue mi sorpresa cuando lé las 'Ideas para una Filosofía de la Historia' de Herder, a quien se acribuye la populatización de Volksgeist, y me di cuenta de que el término apenas aparece en ese libro...!. ... A mí me parece que todo es de origen liberal.» 
providencialismo esencialista, cuando surgirá un Volksgeist laico, heredero genuino del ilustrado; pero para entonces habrá que situarlo en otro paradigma: el de la Völkerpsychologie.

El concepto de sujeto del pensamiento tradicional que vimos antes, negador de la razón individual y defensor de la tradición expresada en lo social, pudo aproximarse a las posiciones del liberalismo a través de un valor tan precioso para el cristianismo como el de la dignidad del hombre. En este momento y cuestión destacaríamos la significación de Jaime Balmes (1810-1848) desde su tradicionalismo católico y el intento de comprensión que realizó respecto de la sociedad convulsa de su época: «sagrado es el hombre a los ojos de cualquiera por su origen y destino, por la imagen de Dios que en él resplandece.... ${ }^{30}$. Esta será una de las vías de «comunicación» entre las historiografías liberaldoctrinaria y tradicionalista. Aunque cuando se trata de aplicar esta imagen del hombre al ámbito político se rechazarán todas las implicaciones del liberalis$\mathrm{mo}^{31}$, rechazo frontal que tendrá sus repercusiones en el ámbito de la historiografía, pues, como destaca José Luis Comellas, en ello residirá una causa principal para la ausencia entre nosotros de una historiografía nacional en todo el primer tercio del XIX español ${ }^{32}$.

Quizás sería ahora, por motivos cronológicos, la ocasión de dejar expuesto el concepto de Historia que tenía Alberto Lista, que cada vez más se nos aparece como la figura capaz de explicarnos, en su trayectoria y en sus propias contradicciones, el paso de la llustración a lo que en España fue el equivalente al Romanticismo europeo del momento, o dicho de otro modo, el intelectual que simboliza lo que el liberalismo, el romanticismo y el historicismo (tal como antes lo hemos considerado), rebajados en sus aristas distinguidoras y unidos por unas circunstancias muy específicas, podían dar de sí en la España de la primera mitad del XIX. Lista ofrece una definición de la Historia que más que por su contenido, de raigambre dieciochesca ( .... las prendas que fácilmente se conciben como necesarias en toda historia: la veracidad, la imparcialidad, grande instrucción en los hechos, mucho discernimiento crítico, sanos princi-

\footnotetext{
${ }^{30}$ Citado por Mulán CHIvite, José Luis: «Persona y sociedad en el pensamiento de Jaime Balmes. Una aproximación a las corrientes ideológicas del XIX español», en Anales de la Universidad de Cádiz, VIl-VIII, 1990-91, pp. 385-401; la cita en p. 391.

31 "Otro de los principios dominantes del progreso es el reducirto todo al individuo...¿ ¿A qué ese prurito de igualarlo todo, de nivelarlo todo? Cuando es más claro que la luz del día que si algún grave peligro amenaza a las sociedades modernas no es por la prepotencia de las jerarquias, sino porque a fuerza de individualizarlo todo, la sociedad ha quedado como pulverizada.»: en Obras Completas de Jaime Balmes, Madrid, B.A.C., 1948-50, Tomo VI, pp. 67-68; citado por VARELA SUANZES, Joaquín, en su «Estudio preliminar» a Jaime Balmes: Politica y Constitución (selección de textos), Madrid, Centro de Estudios Constitucionales, 1988, p. LXX.

32 Ver COMELLAS, José Luis: «Sobre algunos aspectos del nacionalismo español en el siglo XIX. Posibles dificultades para una historia nacional de Españan, en Posibilidades y limites de una bistoriografia nacional, Actas del Simposio celebrado en Madrid, 8-1 2 Marzo, 1983, Instituto Germano Español de Investigación de la Görres Gessellschaft, 1984, pp. 375-382.
} 
pios en moral, política y legislación»), nos interesa por la ubicación que nos ofrece para esta disciplina en el conjunto de los saberes de la época y que nos dan la pista de su consideración para todo el siglo: "Estas cualidades no pertenecen a la literatura propiamente dicha [no olvidemos que el concepto de Literatura incorpora entonces a la Historia como género didáctico]; pertenecen a la filosofía y a la erudición, y deben imponerse en todo escrito histórico" ${ }^{33}$ (cursivas P.J.Ch.). Si la erudición y la filosofía son los límites entre los que debe de moverse la Historia en el siglo XIX, es claro que la que se quedó con la preeminencia sobre nuestra disciplina fue la primera. Eruditos fueron los que la cultivaron durante todo el siglo al amparo de las Instituciones del liberalismo español (Real Academia de la Historia, Escuela Superior de Diplomática) y eruditos fueron los que pasaron luego, de estas instituciones a desempeñar cátedras universitarias desde donde concibieron la Historia tal y como la conocemos ahora, en sus dos facetas de docencia e investigación ${ }^{34}$. La discusión acerca del carácter científico de la Historia sólo llegará con el cambio de siglo (Azcárate, Julián Ribera, Pedro Dorado Montero, Altamira), donde se dirimirá fundamentalmente la ubicación de la Historia respecto de las demás ciencias sociales. Para entonces, los eruditos ya venían contando, facilitado por el ambiente positivista del último cuarto del siglo XIX en España, con el «método histórico», referido fundamentalmente a la depuración crítica de las fuentes (es lo que les interesaba a ellos, porque la verdad es que el positivismo proponía bastante más que eso ${ }^{35}$ ), pero además acompañado de toda la carga ideológica nacionalista del Historicismo opuesta al universalismo ilustrado de los philosophes y su correspondiente concepto de historia ${ }^{36}$. Pero ya nos estamos adelantando al siguiente período del romanticismo que pasamos a considerar inmediatamente.

La segunda fase del romanticismo español, que denominábamos de «nacional-romanticismo» (1844-1868), se caracterizaría por la aparición de las obras de Historia general (nacional) que dominarán todo el periodo isabelino, sobre todo la de Modesto Lafuente, pero también las de Gebhardt, Patxot y Ferrer y otras $^{37}$, en las que nos vamos a encontrar con una serie de rasgos comunes que

33 LISTA Y ARAGÓN, Alberto: Ensayos literarios $y$ criticos, Tormo primero, Sevilla, Calvo-Rubio y Compañía Editores, 1844 , p. 80.

34 Ver al respecto, de Pejró Martín, Ignacio y Pasamar Alzurí, Gonzalo: La Escuela Superior de Diplomática (Los archiveros en la Historiografía Española Contemporánea), Madrid, Anabad, 1996.

35 Ver CARreras ARes, Juan José: "Ventura del positivismo", en Idearium, Revista de Historia y Teorta Contemporánea (Málaga), Vol. 1, 1992, pp. 13-21.

${ }^{36}$ Remitimos de nuevo a los trabajos de Pedro Ruiz Torres y Gonzalo Pasamar Alzuría citados supra.

37 Ver MOReno Alonso, Manuel: Historiografía romántica española, Sevilla, Servicio de Publicaciones de la Universidad, 1979, donde en las pp. 316-317 expone la lista de historias generales desde 1840 a 1873-75, aunque el auror introduce en ella la de Tapia, que nosotros hemos considerado de otro género $\mathrm{y}$, por razones cronológicas, no incluye las Historias generales de la Restauración, como la inacabada Historia General de España, dirigida por Cánovas del Castillo, ni la de Miguel Morayta; la de Altamira no se empezaría a publicar sino a partir de 1900 . Para estas últimas 
habría que mencionar rápidamente. En primer lugar una acentuación de los componentes nacionalistas en un sentido herderiano ${ }^{38}$, que «significaba la relación orgánica entre la Edad Media católica de España, su Romancero y su Poema del mío Cid" ${ }^{39}$. Jover Zamora destacará la disyunción que se dará entre «historia nacional» y "proyecto nacional» ${ }^{40}$, que no hará más que refrendar el carácter conservador y acomodaticio de unas élites burguesas que no tienen un proyecto integrador y de futuro para el país y prefieren mantener las posiciones conseguidas en alianza con los estamentos privilegiados del Antiguo Régimen. Los autores de Historiografía y nacionalismo español nos revelan el providencialismo común a todas ellas, desde las más conservadoras (Gebhardt) a las más progresistas (Patxot y Ferrer) ${ }^{41}$, ya que por debajo de diferentes visiones políticas o consideraciones de lo religioso latía una misma visión de España en base a dos hechos incontrovertibles para todos: la Reconquista como proceso histórico constituyente y el carácter de sus habitantes (=espíritu del pueblo), que se hacía residir «en un pasado lo bastante lejano como para que sus auténticos orígenes resultaran insondables" (en cualquier caso, y a mi juicio, cabe mayor interés aún en anotar que esa visión providencialista de la Historia, salvo las excepciones progresistas anotadas, va asociada, expresamente, en el grueso de la historiografia del nacional-romanticismo, al factor religioso con toda su carga esencialista). Y, por último, derivado de ese peculiar concepto de historia nacional retrospectiva que nos define Jover Zamora, la exclusión en todas estas obras de una consideración hacia el «pueblo» o la «nación» reales, que implicara, de alguna manera, su intervención en la marcha del país ${ }^{42}$.

Hemos comprobado que la historiografía hasta aquí analizada responde a un esquema cuyo protagonista y receptor principal será el sector de la burguesía que domina los resortes del poder político y cultural, que respondería, por tanto, a los principios del moderantismo o liberalismo doctrinario en cuanto a la síntesis de libertad y providencialismo, cuya definición de soberanía residiría en el par Cortes-Rey, cuyo carácter liberal originario se encuentra muy atenuado por un sentido elitista y antipopulista y que elabora una historia de ascen-

ver Ignacio Peiró Martín: Las guardianes de la Historia, Zaragoza, Institución Fernando el Católico, 1995, pp. 153-69.

38 Ver al respecto los trabajos de Hans JURETSCHKE, donde se aprecia la introducción en España del romanticismo alemán de carácter historicista herderiano de la mano de los hermanos Schlegel, y a través de Böhl de Faber y Agustín Durán: especialmeate «El problema de los orígenes del romanticismo español», en Historia de España de Menéndez Pidal, dirigida por José María Jover Zamora, Tomo XXXV, Vol. 1, Madrid, Espasa-Calpe, 1989, pp. 3-209.

39 Ver SILVER, Philip W.: Ruina y restitución, op. cit., pp. 50-58, la cita de la p. 51.

40 Jover Zamora, José María: La civilización española a mediados del s. XIX, Madrid, EspasaCalpe, 1991, pp. 165-169.

${ }^{4 l}$ Cirujano, Paloma; Elorriaga, Teresa y Pérez Garzón, Juan Sisinio: Historiografía y nacionalismo español (1834-1868), Madrid, C.S.I.C., Centro de Escudios Históricos, 1985, pp. 85-91.

${ }_{42}$ Ver SILver, Philip W.: Ruina y restitución..., op. cit. espec. pp. 44, nota S0, p. 50, nota 69 y pp. 55-56.

Hispania, LX/1, núm. 204 (2000) 255-287 
diente herderiano y nacionalista pero con un particular sentido retrospectivo que fusiona pasado y presente sin recabar un proyecto integrador de país de cara al futuro. Se trataría, por tanto, de una historiografía que respondería a una variante específica del Volksgeist entendido como espíritu del pueblo con un fuerte componente religioso esencialista, que conforma una nación cuyos orígenes se pierden en la noche de los tiempos, nación que está por encima de la voluntad de los individuos que la forman. Así es como veremos llegar este concepto de historia al propio Cánovas del Castillo, que lo someterá a una particular interpretación, por cuanto él pretenderá seguir salvando la libertad individual, por lo menos a nivel teórico y para la minoría dirigente, tan cara a los liberales históricos.

La Revolución de 1868 marca un hito en toda nuestra trayectoria. Alrededor de la misma se produciría lo que José Luis Millán Chivite llamó la "epifanía del hombre nuevo» ${ }^{43}$, donde nos sitúa en un proceso histórico en el que la minoría intelectual y política del momento encabezará la conformación de una serie de grupos ideológicos animados, todos ellos, por ese espíritu de «hombre nuevo", hombre nuevo individual ${ }^{44}$ (que nuestro autor nos hace ver acompañado por un particularmente definido "hombre nuevo colectivo", en el que, a pesar de ello, tampoco nos escamotea la vigencia última de los individuos particularmente considerados). La tipología del «hombre nuevo" que establece Millán Chivite abarca, por tanto: liberales históricos, liberales radicales, «demócratas de cátedra», demócratas individualistas, demócratas socializantes, un paradójico, pero real, hombre nuevo tradicional, y, ya en un momento postetior, neoliberales y colectivistas-socialistas en su doble vertiente, ácratas y autoritarios. Para todos ellos establece cuatro rasgos básicos ${ }^{45}$ : la preponderancia de la lucha de ideas sobre la fuerza, la algarada y el pronunciamiento que habían sido moneda corriente hasta entonces en el XIX español; consecuencia de ello, una actitud legalista, para resolver los problemas (con una única excepción, en

\footnotetext{
${ }_{43}$ Recurrimos a este autor porque ya a la altura de 1975 estableció una forma de abordar la Historia política, en un contexto historiográfico español y europeo dominado por lo social y lo económico, que supone adelantarse, en criterios metodológicos y rratamiento del sujeto histotiográfico a lo que mucho después nos propone el anteriormente citado François-Xavier Guerra en la órbita de la Nueva Historia Política. Desgraciadamente José Luis Millán Chivite ya no está entre nosotros debido a su fallecimiento hace unos años, en plena madurez investigadora, pero con permiso del que fue su director José Luis Comellas, y con la inestimable ayuda del Catedrático de Historia Antigua de la Universidad de Sevilla Genaro Chio García, hemos podido consultar su tesis doctoral titulada El bombre nuevo en la Generación española de 1868, Sevilla, 1975. De esta tesis el autor publicó un libro a modo de resumen: Rezolucionarios, reformistas y reaccionarios (Aproximación a un estudio de la generación de 1868), Sevilla, Servicio de Publicaciones de la Universidad, 1979; así como un artículo: «La Generación española de 1868 en la Historia", en Hispania, $n^{\circ} 142$, 1979, pp. 379-391.

44 «El hombre nuevo individual se centra, ante todo, en las élites y en parte de los pequeños burgueses. Responde a personas concretas, con una preparación cultural suficiente, conscientes de los postulados filosóficos e ideológicos, políticos o culturales", en: MILLÁN CHIVITE, José Luis: El bombre nuevo en la Generación española de 1868, op. cit., pp. 166.

4s lbid., pp. 187-191.
} 
este caso, la de quien el autor denomina «hombre ignoto colectivo"); "una visión dicotómica del ser de España»: cada tipo de hombre nuevo trasluce un concepto distinto de España; y, por último, un realismo sociológico, que, a nuestro juicio, estaría anunciando el periodo restauracionista posterior, más que calificar la propia época revolucionaria. Serán singularmente Castelar y Pí y Margall quienes pondrán más empeño en esta exaltación del individuo ${ }^{46}$, en conexión directa con su reivindicación política de sufragio universal, frente al sufragio censitario que siempre sostuvieron los doctrinarios o frente a la ignorancia pura y simple del derecho de elección de representantes políticos de la que hizo siempre bandera el sector más reaccionario del panorama político español. Ambos autores hacen convivir esta radical consideración del individuo humano, sin aparente contradicción (algo muy corriente en el XIX español: la asunción en amalgama a veces inextricable de las diferentes teorías intelectuales europeas más en boga), con un hegelianismo que informa su concepción de la Historia, basado en los siguientes puntos ${ }^{47}$ : monismo metafísico o doctrina del principio único basado en la unidad de la razón; principio de la inmanencia, derivado del proceso de secularización que venimos considerando en este trabajo; ideal de progreso; y principio de la contradicción como motor de cambio.

La propuesta de Millán Chivite es interesante para situarnos en un contexto de exaltación del individuo, de explicar la realidad social según el consabido principio de inmanencia ${ }^{48}$, cuyas repercusiones trascenderán inevitablemente al orden social e histórico ${ }^{49}$ y que presenta un problema inaplazable para sus proponentes: se requiere urgentemente una teoría social que informe sobre el funcionamiento de la sociedad sin acudir a elementos trascendentes a la misma. De esta problemática se seguirá el origen de las ciencias sociales, que en España se sitúa en el krausismo y sus diferentes derivaciones ${ }^{50}$.

La necesidad de una teoría social surgirá, en efecto, desde el propio concepto de sujeto que la reclama. Y ello es así por la siguiente razón: los autores que

\footnotetext{
46 «El hombre será valorado como soberano dotado de una dignidad sagrada y divina, fuente de todo valor trascendente e inmanente, y con una dependencia absoluta e incondicional respecto de rodas las superestructuras mitologizadas, ya religiosas o nacionales», en: MILLÁN CHIVITE, José Luis: Revolucionarios, reformistas y reaccionarias..., op. cit., p. 85.

47 Ver ABELLAN, José Luis: Historia Critica del Pensamiento Español, Tomo IV, Madrid, EspasaCalpe, 1984 , p. 565.

48 aEl hornbre, singular y concreto, ocupa, a partir de ahora, el centro de toda la vida social; (...) hasta la formulación de esta concepción antropocéntrica de la sociedad, extendida por los demócratas, las instituciones y las personas que simbolizaban a todo un pueblo eran realidades superiores mitificadas a las que se debía respeto y sometimienton, en: MILLÁN CHIVITE, José Luis: Revolucionarios, reformistas y reaccionarios..., op. cit., p. 46.

49 «En el fondo lo que se libraba no era tanto la formulación jurídica de unos derechos, sino la defensa del concepto tradicional del ser de España o el triunfo de un nuevo concepto de su nacionalidad», en: lbid., p. 48. XXI.

so Ver Abellán, José Luis: Historia Crítica del Pensamiento Español, Tomo IV, op. cic, capítulo
} 
han venido requiriendo la secularización de los principios por los que se ha regido la sociedad, que han apuntado expresamente al hombre como único principio y fin de todo lo humano -independientemente de que articule su realidad en sociedad, junto con los demás individuos-, se han encontrado con un problema que, con el tiempo, se ha convertido en el verdadero problema de las ciencias humanas: el auténtico problema del sujeto: ¿cuál es el modelo de persona al que se supone que se le hace protagonista y recipiente de los derechos humanos? Porque la realidad que vemos es que todos los teorizadores de lo humano sólo cuentan con un modelo de hombre: ellos mismos; cada uno de los filósofos y teóricos sociales en particular obtienen de este modo, esto es, observándose a sí mismos, el único modelo del que pueden hablar. Es por este motivo que hemos asistido, en el pensamiento de la modernidad, a la configuración de un «ideal filosófico de vida» ${ }^{51}$ que responde a la vida de los filósofos que lo han formulado, en base al cual se acuñan modelos de comportamiento para todas las facetas del desenvolvimiento humano: para el arte, captando lo «sublime», sólo reservado a unos pocos elegidos; para el conocimiento, los sabios, los «espíritus libres» de Nietzsche, en oposición a los que él llamaba eruditos, sólo ocupados en recopilar esas pequeñas menudencias de la vida cotidiana; para la moral: los que son capaces de juzgar elevándose más allá de las reglas sociales que estipulan lo que está bien y está mal para una sociedad y un momento concretos y proponen nuevas reglas de vida más justas, más acertadas que las preexistentes; para la religión: los que son capaces por sí mismos de practicar una religión natural sin tener que ajustarse a las doctrinas y preceptos que impone una religión positiva. En todos estos casos los únicos capaces de actuar así serán los filósofos, los que, por las razones que sean (aquí está el meollo de la cuestión) son capaces de elevar las capacidades que comparten con todos los demás, por encima de su habitual uso.

Es tradicional en el Romanticismo referirse a la figura del genio. En el ámbito de las artes su presencia es indiscutible ${ }^{52}$. Pero no sólo en las artes: su aparición en la actividad intelectual del período previo al 68 es constante. Un autor que no ha sido considerado anteriormente pero que resulta oportuno en el momento cronológico de este trabajo, no sólo por su dedicación a la filosofía de la historia, sino sobre todo por lo paradigmático de su trayectoria, iniciada en el doctrinarismo pero que, a raíz de la amenaza populista del período revolucionario del 48 , basculará definitivamente hacia el tradicionalismo y el autoritarismo es la de Juan Donoso Cortés (1809-1853). Del mismo, extraemos este apunte: "Todo lo que hay en las muchedumbres está de una manera más perfecta en una aristocracia, y de una manera incomparablemente más perfecta y

51 Ver Bermejo Barrera, José Carlos: Entre Historia y Filosofia, op. cit.: «¿Qué es un filósofo?", pp. 45-67.

${ }_{52}$ Baste sólo un ejemplo para un tema inagorable: HenArEs, Ignacio y Calatrava, Juan A.: Romanticismo y Teoria del Atte en España, Madrid, Cátedra, 1982: «La filosofía estética: el genio», pp. 18-20.

Hispania, LX/1, núm. 204 (2000) 255-287 
más alta en una personas ${ }^{53}$. Pero el tema del genio no se agota en su constatación generalizada en todo el periodo considerado romántico hasta 1868. Como dijimos más arriba, en el análisis y puesta al día de las teorías más recientes sobre el Romanticismo, sería a partir de 1868, según Juan Luis Alborg, cuando se dará el verdadero "alto romanticismo» en España, el que pondría por encima de toda consideración al sujeto individual, al yo. El tema del genio, por tanto, seguirá subsistiendo en lo que queda de siglo, quizás de una manera más consolidada, más dispuesta a compartir el mundo de los unormales", por decir así, que antes ${ }^{54}$. Sería como decir que hay sujetos individuales que cumplen mejor que otros, no ya lo que se espera de ellos conforme a un patrón previamente establecido, sino la propia condición humana ${ }^{55}$.

La cuestión no es en absoluto baladí a los efectos de este trabajo: en base a ella es como podemos afirmar, entre otras cuestiones mayores, el carácter subsidiario del historiador, en cuanto tal, respecto de otros desempeños del conocimiento en todo el siglo XIX. El historiador se verá como un mero servidor de las necesidades de otros intelectuales de capacidad superior que realicen la síntesis genial, la Historia ideal, mientras ellos continúan con su trabajo erudito de recopilación de documentos en los archivos: «La naturaleza reparte desigualmente sus dones: a unos da el genio filosófico (...); a otros el talento literario (...); a otros, finalmente, negó estas dos facultades tan grandes como peligrosas, y ni les dio poder de síntesis ni poder de estilo, pero sí diligencia incansable, amor a la verdad por sí misma, celo de propagarla y difundirla, perseverancia modesta en la indagación de cada detalle, espíritu curioso y ordenador que desentierra y reúne los materiales de la historia futura.(...) De estas tres naturalezas tiene que participar en mayor o menor grado el historiador perfecto, y por eso nada hay tan raro y difícil como su hallazgo, y a veces se necesita la labor de un siglo para preparar su aparición. Pero una cosa hay de todo punto evidente, y es que ni el genio de la historia filosófica, ni el genio de la historia artística, están reservados sino a un cortísimo número de mortales privilegiados (...); el único medio de acelerar la aparición del genio de la Historia y de aguardar con más paciencia su venida, será irle preparando y desbastando los materiales de su obra, y darle así allanada la mitad de su camino»s6. La consi-

${ }_{33}$ En Obras Completas de Juan Donoso Cortes, edición de Hans Juretschke, Madrid, B.A.C., 1946, Tomo II, pp. 538-39, citado por Rodrigo FerNÁNDEZ-CARvajAL: «Las constantes de Donoso Cortés", en Revista de Estudios Politicos, $\mathrm{n}^{\circ}$ 95, 1957, pp. 75-107, la cita en p. 83.

s4 Ver de GonzÁlez SerRaNo, Urbano (principal representante del Krausopositivismo en España: ver JIMÉNEz GARCís, Anronio: El Krausopositivismo de Urbano González Serrano, Badajoz, Diputación Provincial, 1996): «Psicología del genio", en Revista de España, $\mathrm{n}^{\circ}$ 91, 1883, pp.455-466.

ss Véase al respecto Bermejo BarRera, José Carlos: El Final de la Historia, op. cit., pp. 117 y ss.

36 Menḱndez Pelayo, Marcelino: "Contestación» a Antonio Rodríguez Villa: Discursos letdos ante la Real Academia de la Historia en la recepción pública del Excmo. Sr. D._, el 29 de Octubre de 1893, Madrid, Establecimiento Tipográfico de Fortanet, 1893, pp. 106-7. Recordemos la anterior 
deración del historiador como erudito, frente a la del literato o a la del filósofo (los tres aspectos que Lista hacía integrar en la Historia y que no varían en todo el siglo XIX), es declaradamente humilde por la aparente modestia de sus propósitos, que cualquiera puede, en definitiva, alcanzar.

De la Gloriosa en adelante el movimiento que informa la renovación de la cultura española es el krausismo. Julián Sanz del Río basa su filosofía en la elección del yo como fuente de certeza, como principio de toda ciencia, apoyado en lo cual elabora una filosofía de la historia donde la asimilación de las edades del hombre (infancia $=$ edad de la inocencia, juventud $=$ edad opositiva, madurez = edad de la armonía) con las edades de la humanidad se hace más que evidente. Según nos lo refiere la autora a quien seguimos en este momento: «'Conocer la naturaleza del hombre mismo' es el objetivo de Krause, expresado por Sanz del Río. 'Crear el hombre nuevo', dirá Giner más adelante. Ese es el único fin que persiguen los krausistas» ${ }^{57}$.

Adolfo Posada (1860-1944), uno de los primeros y mejores representantes de la moderna Sociología española ${ }^{58}$ y perteneciente a la tercera generación del krausismo, fundamenta su ciencia también en el yo, aunque introduciendo una variante que es la de asimilar la conciencia a lo social, que nos dará ocasión para alguna consideración de interés: «El análisis de la propia conciencia es el método más idóneo para la sociología, por tres razones: $1^{\mathrm{a}}$, la conciencia es una obra social; $2^{a}$, sólo mediante ella llegamos al conocimiento de la realidad social; y $3^{\mathrm{a}}$, merced a la conciencia somos sociales, esto es, nos sentimos y nos damos cuenta de que somos sociales y de que la sociedad es"s9. Este planteamiento, así expresado, no nos resuelve nada, puesto que no nos explica por qué unos sujetos son capaces de ejercer la crítica y elevarse por encima de lo que esa sociedad ha hecho de ellos. Volvemos, por tanto, al tema de las distinciones entre los sujetos individuales, base de toda la problemática que el inmanentismo acarrea a los teóricos sociales.

Nos hemos ido un poco hacia adelante cronológicamente con Posada, pero no nos olvidamos de que nuestro autor clave es Giner de los Ríos, que será el gozne sobre el cual girará nuestro estudio del krausismo y su relación con el sujeto y con la historia. Pero antes de eso, y al hilo del problema planteado por Posada, detengámonos brevemente en un autor como Manuel Sales y Ferré (1843-1910) y en la solución que, desde el positivismo de raíz krausista, inten-

cita de Don Marcelino, que insertamos supra; en ésta, diez años posterior, las cosas no han cambiado dernasiado para él al respecto.

${ }^{97}$ RoDRIGUEZ DE LECEA, M${ }^{2}$ Teresa: Antropología y Filosofta de la Historia en Julián Sanz del Rio, Colección Tesis Doctorales, $\mathbf{n}^{\circ}$ 254/90, Madrid, Editorial de la Universidad Complutense, 1990. La cita en pp. 188-9.

58 Ver SAAvedra, Luis: El pensamiento sociológico español, Madrid, Taurus, 1991, pp. 124-142.

59 Ver LAPORTA, Francisco José: Adolfo Posada, Politica y Sociologia en la crisis del liberalismo español, Madrid, Edicusa, 1974, p. 340; se trata de una adaptación del autor a las palabras del propio Posada tomadas de su obra Principios de Sociología, 1908, (p. 305). 
tará dar al tema de las distinciones entre sujetos. Para ello nos remitimos a su discurso Nuevos fundamentos de la moral ${ }^{60}$. Según nos dice el autor, el ideal moral del individuo está fundado en la moral de su propia sociedad, en cambio, individuo por individuo "no hay dos ideales personales idénticos». Pero observemos dónde hace residir el autor las diferencias: $A \mathrm{~A}$ esta diferenciación concurren varios factores, entre otros la posición económica, el sentido y grado de la educación, la profesión u oficio, la cultura y, sobre todo, la herencia física». Ahora veamos lo que entiende Sales por herencia física: «Varía esta última, principalmente, según la proporción entre la substancia blanca y la substancia gris del cerebro: fija, invariable, asiento de las actividades instintivas, la primera; inestable, plástica, asiento de las actividades conscientes, la segunda». $Y$ ahora atención: «El predominio de la fijeza da origen a un tipo atávico, a un grado inferior de organización, en que privan los procesos automáticos y la capacidad educativa es muy escasa; el predominio de la plasticidad va acompañado de un alto grado de conciencia personal, gran poder inventivo y extraordinaria adaptabilidad a los modelos sociales». Con estas afirmaciones, ¿dónde queda el supuesto progresismo de Sales y Ferré? Pues en que Sales al concebir, -en conformidad con las teorías naturalistas en boga-, el desenvolvimiento de los talentos caracterizados por esos componentes fisiológicos, no acepta otra minoría social relevante que no sea la de la inteligencia, provenga del sector social que provenga: «... los talentos que, por ser hijos de pobres, no se cultivan ni aprovechan, y es incalculable la suma de energías que la sociedad malgasta en capacitar a ineptos..."; aunque haya diferencias personales, al final, y esto también lo aproxima a las interpretaciones naturalistas de la izquierda de su época, debe de prevalecer la armonía social, según la cual «el hombre reconoce en su semejante un igual suyo, establece con él reciprocidad de derechos y de deberes y funda una moral y una sociedad». Pero cuesta creer que con unas diferencias individuales de tal calibre y al parecer medibles por peso de sustancia gris cerebral, que ya no proceden de la clase social o económica sino de algo aún más insalvable como es la propia constitución física, sea posible hablar de armonía social. Estos planteamientos naturalistas hay que insertarlos, como decíamos, en una de las corrientes ideológicas dominantes en el final del siglo XIX como es la del darwinismo.

La interpretación de la Historia se verá inevitablemente condicionada por estas teorías. Esto se puede comprobar por los artículos de Pedro Estasén en Revista Contemporánea ${ }^{61}$. A la burguesía liberal-conservadora en el poder durante la Restauración le vino muy bien una teoría como la planteada por el denominado «darwinismo social», según la cual estará permitido asimilar las leyes

6n SALES y FERRE, Manuel: "Nuevos fundamentos de la moral", 28 de Abril de 1907, en; Dijcursos de recepción y de contestación leídos ante la Real Academia de Ciencias Morales y Politicas, Tomo VIII, Madrid, Establecimiento Tipográfico de Jaime Ratés, 1912, pp. 415-483.

6! Ver: "El positivismo y la teoría de la evolución», Tomo XI, 1877, pp. 420-488, y, sobre todo: «La teoría de la evolución aplicada a la Historia", Tomo IV, 1876, pp. 447-464 y Tomo V, 1876 , pp. 218-234.

Hispania, LX/1, núm. 204 (2000) 255-287 
de la evolución natural al ámbito social e histórico, lo que se hará en el sentido de apoyar científicamente unas posturas de privilegio basadas en la selección natural —en este caso: social- de los mejores, de los más aptos, justificando así el individualismo y el espíritu competitivo inherente al capitalismo. Esto ocurría en un ambiente social y político en el que la denominada "cuestión social» ya estaba empezando a articularse y verse respaldada por una teoría como la del materialismo histórico y demás ideologías revolucionarias basadas en argumentos de estirpe racionalista, no naturalista. Por tanto a la burguesía ya no le servía la razón tanto como antes, cuando se enfrentaba directamente al Antiguo Régimen y sus privilegios: ahora los más desfavorecidos se enfrentan a ella con sus mismas armas; se impone, pues, para la burguesía una nueva vía argumentativa: la idea de la vida ${ }^{62}$. De entre los sectores más desfavorecidos y más aludidos por estos planteamientos sobresaldrán los anarquistas, entonces mayoritarios respecto de socialistas, quienes desarrollarán una argumentación basándose también en Darwin pero en sentido opuesto $0^{63}$.

Antonio Cánovas del Castillo (1828-1897) situatá el concepto de nación en el centro mismo de toda su construcción ideológica y le dará una intensidad sentimental, un empuje pattiótico, que, por un lado, le diferenciará sustancialmente de la historiografía moderada anterior - que, como dijimos, cultivaba un concepto de historia nacional retrospectivo- y, por otro lado, le convertirá en exponente de un proyecto nacional, de una creencia en España como nación, basándose, para ello, en la Historia misma ${ }^{64}$, veamos cómo. Cánovas une en su personalidad la doble condición de político e historiador y ello es algo que nosotros tenemos que tener muy en cuenta porque resume la condición de todo el siglo: la historia vinculada a las necesidades de la política, de manera que para cada corriente ideológica se construirá una visión ad boc de la Historia de España y con ella del propio concepto de nación, tal como vimos en los rasgos comunes que Millán Chivite nos daba para los diferentes grupos que confluyen en la generación del 68. Desde el poder, Cánovas manejará las instituciones de la cultura (Academias, Ateneo, revistas) y con ellas la producción de discurso histórico, personificando así la corriente ideológica y la forma de

62 Para estas cuestiones ver: NúÑEZ RuIZ, Diego: «El impacto del naturalismo y del evolucionismo en el pensamiento liberal y socialista», pp. 66-72; y Bernat MUNieSA: El impacto del darwinismo en el pensamiento social", pp. 81-84, ambos en Antbropos, $\mathrm{n}^{\circ} 16-17,1982$.

63 «No existe tal lucha por la existencia, interpretada en sentido malthusiano (escasez natural, forzosa extinción de los débiles)...; la burguesía no ha demostrado ser la 'más apta' en la lucha por la existencia, sino que compite desde una posición privilegiada; (...) es la cooperación, y no la lucha, lo que produce el desarrolto de las facultades más valiosas de los individuos y de los grupos, y ésta es una característica especialmente típica de la especie humanan, en: ALVAREZ JUNCO, José: La ideologia politica del anarquismo español (1868-1910), Madrid, Siglo XXI, 1976, pp. 142-144.

64 Ver para todo este punto: DARDÉ, Carlos: "Cánovas y el nacionalismo liberal español», op.cic., pp. 230-234. 
"hacer historia» dominantes en el último cuarto de siglo XIX ${ }^{65}$. Entre los estudiosos actuales de la figura de Cánovas no existe un consenso generalizado acerca del significado ideológico-político del prócer del sistema restauracionista. Esperanza Yllán ${ }^{66}$ es la autora que podríamos situar, a estos efectos, en el centro de todas las discrepancias. Respecto de su libro citado en nota, autores como Jover (en el prólogo a dicha obra) y Abellán ${ }^{67}$ están básicamente de acuerdo con las tesis que sostiene, mientras que Pasamar y Peirób ${ }^{68}$ critican de entrada la propia metodología empleada por la autora en su estudio. Pero es respecto del artículo de Yllán, que citamos en la misma nota junto con su libro, donde nos detendremos en las discrepancias ideológicas. Esta autora coloca a Cánovas junto al tradicionalismo, como un pre-ilustrado, cuando no antiilustrado, esencialista en su concepto de nación, providencialista y antiuniversalista (todos estos son términos que aparecen en su artículo). Carlos Dardé69 criticará abiertamente el contenido del artículo de Yllán aludiendo a la descolocación histórica a la que esta autora somete a Cánovas. Para Dardé, Cánovas sigue, con matices, la estela del moderantismo, del liberalismo doctrinatio ${ }^{70}$, significadamente en su fórmula Rey-Cortes como constructora de la legitimidad del estado, con su negación del sufragio universal, su salvaguarda del derecho de propiedad y su apelación al buen sentido de las minorias rectoras. Pero al Estado será la nación la que le dé contenido, una nación en cuya explicación de su desenvolvimiento encontramos el típico sustrato de la teoría de la Historia cristiana, neotomista del momento (donde aparece la figura influyente del Cardenal Ceferino González) formado por el par Providencialibertad. Las naciones son obra de la Providencia, pero será la Historia, según Cánovas, quien nos las explique, son los hechos humanos en un largo proceso de sedimentación los que las han ido produciendo a lo largo de la historia. Esta apelación a la Historia diferenciará a Cánovas de Renan y su voluntarismo,

6s Ver al respecto de PeIRó, Ignacio: Los guardianes de la Historia, op. cit.; «Los historiadores oficiales de la Restauración (1874-1910)", en Boletín de la Real Academia de La Historia, tomo CXCIII, 1996, pp. 13-72; y «Los acadérnicos de la historia o la imagen ideal del historiador decimonónicon, en Studium (Teruel), nº 4, 1993, pp. 83-104; y de PeIRó MARTin, Ignacio y PASAMar ALzURía, Gonzalo: La Escuela Superior de Diplomática, op.cit.; y «La 'vía española' hacia la profesionalización historiográfica», en Studium (Teruel), $\pi^{\circ} 3,1991$, p. 135-162.

${ }^{66}$ De esta autora tenemos en cuenta, por un lado, su libro: Cánovias del Castillo, entre la bistoria y la politica, Madrid, Centro de Estudios Constitucionales, 1985; y, por otro lado, su artículo "Historia y nación en Cánovas del Castillow, en Estudios Historicos: Homenaje a los profesores José Maria Jover Zamora y Vicente Palacio Atard, Madrid, Universidad Complutense, 1990, pp. 137-150.

67 Ver su Historia Critica del Pensamiento Español, Tomo V-1, Madrid, Espasa-Calpe, 1989, pp. $511-515$.

68 Ver su obra en colaboración: Pasamar Alzuría, Gonzalo e Peiró Martí, Ignacio: Historiografía y práctica social en España, Zaragoza, Prensas Universitarias, 1987, pp. 7-8-, nota 10.

69 Ver su artículo *Cánovas y el nacionalismo liberal español», op. cit., pp. 220.221 y passim.

${ }^{70} \mathrm{El}$ aval para tal consideración lo tendríamos en DíEZ DEL CORRAL, Luis: El liberalismo docarinario, op. cir., especialmente en sus dos últimos capítulos, reservados a Cánovas. 
pero también le diferenciatá de posturas abiertamente esencialistas: teniendo en cuenta que en su momento histórico y más aún con su posición política y social, nunca habría puesto en cuestión la unidad y etetnidad de la patria, Cánovas no obstante recurre a la Historia, que está sujeta a las acciones de los individuos y donde, por tanto, lo que fue de una manera podría haber sido de otra.

Llegados a este punto es donde vamos a analizar el concepto de sujeto en Cánovas. Dicho concepto se esconde bajo uno de los dos miembros del par Providencia-libertad ${ }^{71}$, que no puede ser otro que el segundo, la libertad, el libre albedrío. La palabra clave que aparece siempre en estas disquisiciones es la de "fatalismo". Se trata de un término que repele por su negación de la libertad: «La gran cuestión que hoy separa a los panteistas o simples materialistas, de un lado, y de otro a los cristianos y deistas, es la del fatalismo: cuestión que no puede ya dejar en olvido nadie que trate de historias ${ }^{72}$. Frente al fatalismo se alza el libre albedríio ${ }^{73}$. Hasta aquí no tendría por qué haber ninguna dificultad en sumarse a las afirmaciones de Cánovas. En su contra, los fatalistas abogarian por la existencia de leyes sociales que explicarían el discurrir de las sociedades formadas por la agrupación de individuos que no siempre están en la disposición de ejercer las posibilidades que les ofrece su libre albedrío y no tienen más remedio que acomodarse a las circunstancias, a veces insalvables, que les condicionan socialmente. En el fondo de esta diferenciación se encuentra, evidentemente, la cuestión social, de la que sus principales protagonistas están empezando a organizarse ya de una manera oficialmente reconocida por el artículo 17 de la Constitución de $1869^{74}$, como fuerza social y política alternati$\mathrm{va}^{75}$. Pero, para terminar con Cánovas, comprobamos, como sospechábamos,

" «Quitad la presciencia y Providencia divina que dirige a fines determinados el movimiento de la humanidad así como también dirige las acciones del individuo, y tendréis una filosofía de la historia sin una de las condiciones esenciales de la ciencia que es la unidad;(...) Quitad por otro lado la libertad humana, y habrés convertido la filosofia de la historia en la física de la historia o hablando con más propiedad en la historia del fatalismo humano", en: GoNZALEZ, Ceferino: «La filosofía de la historias (1870), en Estudios religiosos, filosófficos, cientificar y sociales, Madrid, Imprenta Policarpo López, 1873, pp. 1-181; la cita en p. 19.

72 En: Antonio Cánovas del Castillo: «Contestación» en: Godoy AlCÁNTARA, José: Discursos leídos en la Academia de la Historia en la recepción pública de Imprenta y Estereotipia de M. Rivadeneyra, 1870, p. 77.

73 "En todos los climas, por todos los terrenos, con cualesquiera condiciones fisicas, demuestra, cuando quiere, el ser humano que Dios le hizo señor de todas las fuerzas ciegas de la Creación, $y$ que ninguna potencia fisica ejerce influjo perenne sobre su libre albedrion, Ibid., p. 78.

74 Ver Luis ABellán, José: Historia Crítica..., Tomo V-1, Madrid, Espasa-Calpe, 1989, pp. $56 s s$.

"Existe toda una hisroriografia procedente de este ámbito, representada singularmente por la obra de Fernando Gacrido (1821-1883) [ver AJA, Eliseo: Democracia y socialismo en el siglo XIX español: El pensamiento politico de Fernando Garrido, Madrid, Edicusa, 1976, especialmente pp. 37ss., pafa entender su ucilización de la Historia], que propone repensar la historia de España en la reivindicación de los derechos de toda una clase social -sujeto histórico de esta historiografía del socialismo utópico español, porradora en su conjunto del libre albedrío que reclama su efectiva realización-, la clase social de los desheredados y excluidos de los privilegios que hasta entonces sólo unos 
que ese libre albedrío que se opone al fatalismo sólo es cualidad de ciertos sujetos individuales, no de todos. Pero la Historia no se podría explicar mediante las acciones de esos pocos individuos libres, la Historia es mucho más complicada que todo eso. Entonces, para poder aspirar a su comprensión, a su inteligibilidad, Cánovas, donde los fatalistas ponen las leyes de la estructura y evolución histórica, allí él sitúa a Dios ${ }^{76}$. Y lo que cabe preguntarse aquí es por la diferencia de tipo humano que hay entre quien opta por apelar a Dios y a la Providencia para "explicarse» eso desconocido que conforma lo situado más allá de nuestro ámbito de acción, más allá de aquello que se puede controlar o intentarlo siquiera con nuestros solos medios, y quien opta por indagar en ese mundo social e histórico que, sin duda cree él, se mueve por unas reglas que es posible conocer e intentar dominar: no sería fatalismo lo que se obtendría en este último caso, sino precisamente la posibilidad de tener más libertad, y podérsela ofrecer, en forma de conocimiento, a los demás.

Será Francisco Giner de los Ríos (1839-1915) quien desde sus convicciones krausistas y un afán pedagogista inherente a dicha filosofía, intentará la renovación de la sociedad española por la vía de crear una minoría de individuos capaces de imbuir en la sociedad el ideal del hombre nuevo, la utopía krausista que persiguió durante toda su vida. El interés de Giner está, más que en la propuesta social que plantea, quizás debido a los condicionantes de su momento histórico y que no deja de ser, al fin y al cabo, minoritaria y elitista, en la posibilidad que ofrece de que su utopía, en sus aspectos teóricos, pueda encarnarse en todos los individuos de una manera accesible, sin poner barreras insuperables para su consecución, sean de tipo social o natural, como era moneda corriente entre doctrinarios y darwinistas de fin de siglo.

Donde mejor se deja ver el ideal de persona que maneja Giner y todo el krausismo, lo utópico de su propuesta, es en su concepto de religión. En lugar de mantener esa distinción de la que hablábamos en su momento, típica de los pensadores de la Modernidad, a la hora de diferenciar a los hombres según su capacidad, en este caso de llegar a la experiencia religiosa por sí mismos (religión natural) o por su necesidad de contar con ayudas para conducirse en el tránsito hacia la otra vida a través de una serie de ritos e interpretaciones de lo sagrado (religión positiva), en el krausismo hay una apuesta incondicional por la religión natural: todos los hombres, por el hecho de ser racionales, deben de

pocos habían disfrutado. Su contenido sería el de la denuncia de los abusos de esa minoría privilegiada centrándose singularmente en la cobertura ideológica que siempre le suministró la Iglesia oficial: el anticlericalismo es uno de los rasgos más definitorios de estas obras.

76 «Si la verdad, la belleza, la conciencia del derecho pueden residir íncegras en cal o cual individuo intelectualmente privilegiado, la historia, por el contrario, no puede realizarse sin el concurso de todos los individuos altos y bajos, pasados, presentes y venideros; y el secreto de esta suma inmensa, de esta resultante de tantísimas fuerzas desiguales y heterogéneas, tan sólo Dios es capaz de alcanzarlo", en: Antonio Cánovas del Castillo: "Contestación”, en GodoY AlCáNTARA, José: Discursos..., op. cit., p. 79. 
ser capaces de llegar al conocimiento de Dios por sí mismos, sin intermediarios institucionales de ningún tipo, con lo cual se produce una tensión muy difícil de soportar por parte de la generalidad de una población como la española, tan acendrada y secularmente católica, y particularmente por parte de sus órganos directores, la Iglesia española, muy celosa de sus privilegios y prerrogativas. Gómez Molleda, tan sensible a esta cuestión, no puede por menos de suspirar por un Giner (lo cual sería extensible a todos los krausistas) que hubiera vertido su afán renovador en los «odres viejos» de la tradición española, en lugar de enfrentarse frontalmente a ella como hizo ${ }^{77}$. El krausismo considerará siempre la religión "como un sentimiento íntimo de dependencia entre Dios y el hombre, donde religión y filosofía se funden sin que sus fronteras queden nunca delimitadas, alejándose siempre de todo confesionalismo... $>^{78}$. Por supuesto que no hace falta repetir que para el krausismo el motor de toda la renovación nacional a la que aspiran es el sujeto individual ${ }^{79}$. Otra cosa será cómo el krausismo conciba la sociedad, en base a su organicismo de raíz ética y su división en esferas de actividad.

Persona, para Giner, es igual a ser racional y esto debe quedar patentizado tanto en el conocimiento ("poder darnos cuenta de lo universal de las cosas, de indagar y edificar la ciencia»), como en el sentimiento ("elevarnos sobre la afección inmediata y del instante por cosas y personas individuales, al amor objetivo del ideal») y en la voluntad («dirigida al bien según su vocación y aptitudes»), en definitiva: «la racionalidad es el poder de ser y vivir, más allá de lo limitado y la hora presente, en lo ilimitado y de todas las horas ${ }^{80}$. Pero el problema que debemos de elucidar aquí no es el de la racionalidad aplicada a la vida, sino el de cómo se consigue, es decir, no el objetivo final de la pedagogía krausista sino el medio de llegar a él. Giner se mueve entre dos términos, individuo y persona, para definir, respectivamente, lo más subjetivo en el hombre y la redención que de tal estado se realiza por medio de la razón, convirtiéndole en un ser capaz de elevarse por encima de su condición limitada hacia la acción común con los demás hombres ${ }^{81}$. Giner reclama de la conciencia del hombre "el impulso que ha de guiarle en el carnino de la vida»; observemos el empleo

7 GOMEZ MOLLEDA, M². Dolores: Lor reformadores de la España contemporánea, Madrid, C.S.I.C., 1966, XXXI: lo que hemos reproducido aquí es una reflexión de Palacio Atard, autor del prólogo.

${ }^{78}$ Ver LUIS ABELLÁN, José: Historia Critica..., Vol. IV, op cit., p. 464.

79 «Sin la resolución individual del conflicto interno del 'yo' será en vano que el hombre se esfuerce en perfeccionar la sociedad, ya que los antagonismos en ella exiscentes son la réplica de los que el hombre entraña en sín: tomado de Ma. Dolores GÓMEZ MOLLEDA: Los reformadons..., op. cit., p. 58.

80 w Sobre la idea de la personalidad»: en La persona social. Estudios y fragmentos (1899), Obras Completas de Francisco Giner de los Ríos, Vol. VIII, Tomo 1, Madrid, Espasa-Calpe, 1923, pp. 7-45; las citas en p. 29.

81 "En todas nuestras discordancias apelamos a ese testimonio, a la unidad de la conciencia, cuyo fundamento suponemos uno e igual en todos; suposición sin la cual faltaría la base, no ya para la más mínima discusión, sino para toda inteligencia entre los hombres», lbid., p. 40. 
por el autor del término «impulso», y en otros casos también «anhelo íntimo", «inclinación del espíritu», que son anteriores a todo ejercicio de la razón «y cuyo contenido es de muy difícil precisión, pero cuya presencia condicionante es característica ${ }^{82}$. Este impulso prerracional, inscrito en la conciencia, que la hace tender hacia la razón, tiene necesariamente que asentarse en lo individual de cada uno de nosotros, retomando la dualidad establecida por Giner entre persona e individuo. En el individuo residiría lo peculiar y subjetivo, lo relativo y mudable, lo limitado y, del mismo modo, también lo prerracional, lo que nos hace en un momento dado movernos hacia la razón, hacia lo universal, hasta convertirnos en personas. Estamos ya en los terrenos delimitados por el concepto de "vocación", que tanto le gusta emplear a Giner y cuyo proceso de construcción vamos a seguir someramente aquí, por ver adónde nos lleva. Dicho concepto aparece, para los efectos aquí considerados, en su obra Lecciones sumarias de Psicologia (1874) ${ }^{83}$. Nosotros lo relacionaremos necesariamente con ese sustrato individual donde se manifiesta lo más subjetivo de cada uno, donde toman su asiento las diferencias entre los hombres. Si los humanos somos diferentes por nuestra propia condición de individuos, interesa comprobar hasta qué punto esas diferencias nos van a condicionar en nuestra realidad como personas, ejercitadoras de la razón. Dicho de forma acorde con el sentido de este trabajo: iser individuos, y por tanto diferentes unos de otros, nos permitiría a todos por igual alcanzar el ideal de persona humana, ser, por poner el caso paradigmático que todos los pensadores han definido siempre como ideal de persona: filósofos?

Entre los contenidos de una educación integral del hombre estaría precisamente el desarrollo de la «espontaneidad», que permitiría, a juicio de Giner, por el método intuitivo tan característico de su escuela (Unamuno reconoció en él al «Sócrates español»\$4), desarrollar lo mejor de las características individuales de cada personalidad ${ }^{85}$. Esto nos llevaría al pleno desenvolvimiento del ideal de persona gineriano, independientemente de su carácter y temperamento. Pero en lo que interesa aquí incidir es en que la "vocación», según Giner, tendrá que ver necesariamente con las cualidades particulares de cada individuo, en función de los elementos que los diferencian a unos de otros. $Y$ aquí es donde el autor saca el mayor partido de su concepto de «aptitud» ${ }^{86}$. La aptitud es a lo que estaríamos inclinados profesionalmente, y dependería no sólo del espíri-

${ }^{82}$ GÓMEZ MOLIEDA, Ma . Dolores: Los reformadores..., op. cit., pp. 57 (nota 4, texto de Fernando de los Ríos) y 58.

83 En: Obras completas de Francisco Giner de los Ríos, Vol. IV, Madrid, Espasa-Calpe, 1920.

84 Ver Luis Abellán, José: Historia Crítica..., Vol. V-1, op. cir., pp. 158-9.

${ }^{85}$ Para el análisis de las tipologías individuales y el método pedagógico de Giner ver VIILALOBOS, José: El pensamiento flosbfico de Giner, Sevilla, Publicaciones de la Universidad, 1969, en especial las pp. 115-117.

${ }^{86}$ Lo que sigue entre comillas en: GINER DE LOS Ríos, Francisco: Lecciones stmarias de Psicología, loc.cit., pp. 261-263 y 221-2. 
tu sino también de la constitución del propio cuerpo. «La conciencia, irreflexiva o refleja, de estas aptitudes se expresa en la tendencia que nos impulsa al fin dado, y constituye la vocación». El hecho de que cada persona disponga de aptitudes para una profesión no hará que todos aquéllos que hagan coincidir su aptitud con su vocación experimenten la misma efectividad en su elección, habrá grados, que serán la habilidad, el talento y el genio. De nuevo el genio -recordemos la tesis de la Generación del 68 como los genuinos románticos del XIX español--, pero de una manera mucho más atenuada que en otros ámbitos intelectuales, entre otras cosas porque el desempeño de una profesión no es, con Giner, lo que más se puede esperar de una persona, siempre estará por encima su desenvolvimiento integral como ser humano, o dicho de otro modo: alcanzar el ideal filosófico de vida.

La inclinación vocacional, pues, no debe de llevar hacia el exclusivismo especialista: la razón no se puede cerrar en una sola esfera de conocimiento. Y Giner recurre aquí al sentido organicista del krausismo y a su encaje de lo individual en lo social a través de las esferas de actividad y para aclararnos esto el concepto que emplea es el de "voluntad": cada obra que realicemos como expresión de una vocación consistirá en un desenvolvimiento de la voluntad en sus diferentes niveles, desde los actos más nimios que den lugar a dicha obra en el ámbito de lo individual, hasta la constitución de la vocación como realización de una voluntad particular y la conjunción de todas las vocaciones en esferas particulates que constituirán el organismo social. El bien, como objeto que es de la voluntad, se articularía «interiormente" como «un organismo de esferas particulares (la científica, artística, jurídica, moral, religiosa, económica...)».

Si cada individuo debe de "encajar" en una vocación, dicha vocación le deberá permitir, o en cualquier caso será la vía, podemos decir así, de acceder a su condición de persona, entendida como yo racional, universal y permanente. Y si esto es así necesatiamente, debemos de pensar que el desempeño de una «vocación», entendida como adscripción a cualquiera de las esferas de la vida social («órganos» en terminología krausista), será algo secundario, que lo realmente importante es acceder a la condición de persona racional (valga el pleonasmo). Esto lo suscriben todos los krausistas. Llama la atención que cada una de las esferas coincide con una profesión de las llamadas liberales: está claro que para Giner no hay posibilidad de redención a corto plazo para los trabajadores manuales. Y, por otro lado, las vocaciones hemos visto que suponen unas individualidades características detrás: su pleno desenvolvimiento como personas, su aspiración al ideal filosófico de vida nos lleva a plantear la tesis de que sea posible distinguir tantas filosofías o sistemas filosóficos como tipos humanos definibles haya, o quizás como individuos haya; corroborar esta tesis resultaría relativamente fácil acudiendo a las filosofías personalistas y existencialistas ${ }^{87}$.

${ }^{87}$ Aquí proponemos un artículo de entrada: PuCCiAreill, Eugenio: «La filosofia como expresión de un tipo humano", en Actas del II Congreso Nacional de Filosofia (Córdoba, Argentina, junio 
El concepto de persona en Giner no será, por tanto, sino la consecuencia natural de una filosofía idealista, por utópica, que concede al yo la posibilidad consustancial a él de alcanzar la excelencia humana a través de una vía o método de indagación interior en busca de la verdad y los demás valores supremos encarnados a la perfección en Dios. Ningún ser humano puede sustraerse a esta "obligación". La cuestión de que las necesidades reales de un país obliguen a los abanderados de este planteamiento a que sólo una minoría (y que sin remedio vendrá configurada por las disponibilidades económicas de sus componentes) vaya en un principio en pos de ese Ideal, desfigurará, en la práctica y de manera decisiva, el aparente carácter universal que ese Ideal personalizador debería conllevar.

La Historia de España será uno de los principales motivos de reflexión para Giner, al igual que para todo el krausismo 88 . El maestro encontrará en Rafael Altamira, discípulo directo suyo, el historiador que llevará a la práctica (evolucionándolos con ella) sus postulados. El tránsito de un autor a otro coincidiría con el momento en que el krausismo empieza a positivizarse con el nombre de krausopositivismo $0^{89} \mathrm{y}$, por lo que a la historiografía se refiere, coincidiría con lo que ya en Europa se conoce para entonces bajo el paradigma científico social de la Völkerpsychologie, o psicología del pueblo o etnopsicología ${ }^{90}$. La referencia intelectual donde, para los efectos aquí considerados, hay que buscar el enlace entre la tradición krausista y el pensamiento europeo del momento será Wundt y su obra psicológica9!

La historiografía krausista gineriana nos sitúa en los dominios de lo que se conoce como «historia interna». No es la historia de los grandes acontecimientos políticos, tan del gusto tradicionalista y doctrinario. Eso es algo de lo que

1971), Buenos Aires, Edit. Sudamericana, 1973, pp. 110-143. Trabajo que agrupa de manera didáctica y muy sugerente una serie de autores que nos interesan en el sentido aquí aludido, como son: Chartes Renouvier, William James, Wilhelm Dilthey, Georg Simmel, Max Scheler, Karl Jaspers, entre otros.

sa Baste, en este momento, citar un trabajo singularmente preciso, al respecto, de Antonio HEREDIA SORIANO: «El Krausismo español y la cuestión nacional», en Enrabonar (Barcelona), $\mathrm{n}^{\circ} 16$, 1990, pp. 105-121, que amablemente me hizo llegar el propio autor.

g9 Ver al respecto: JIMÉNEZ GarCis, Antonio: El Krausopositivismo de Urbano González Serrano y, sobre todo, NúNEzE RUIZ, Diego: La mentalidad positiva en España, ambos citados supra.

90 Para las nociones que ahora siguen me he valido de cierto trabajo de Ciriaco MORón ARroYo que se me antoja imprescindible: «La teoría crítica de Menéndez Pidal» en Hispanic Review, Vol. 38, no 5, 1970, pp. 22-39. Y en relación con éste: Ciriaco Morón Arroyo et alii: Menéndez Pelayo: bacia una nueva imagen, Santander, Sociedad Menéndez Pelayo, 1983, pp. 11-30.

91 LuIs ABellán, José: Historia Crítica..., Tomo IV, op. cit., ver todo el epígrafe 2: «La importancia de la psicología en el origen de las ciencias sociales", pp. 515-517, donde se cita una obra que, en principio, debetía servir para fundamentar esta relación Wundt-Giner a través de la psicologia y su derivación hacia el concepto de Historia de España krausista: Enrique LAfuENTE NIÑo: La psicología española en la ápoca de (Wundt) la aportación de Francisco Giner de las Ríos, Tesis doctoral (inédita), Universidad Complutense de Madrid, 1978. 
Giner abomina. La historia de España que propone Giner es un trasunto de su imagen del sujeto humano, de la persona, que vimos antes: es filosófica, psicológica y, en lo religioso, es la historia de la mística tradicional y su magisterio de «introspección individualista, como expresión del alma religiosa hispana»: «La verdadera realidad histórica para Giner es el mundo interior del pueblo hispánico, y sus valores, las manifestaciones espirituales de ese pueblo; es lo humano racional con las notas propias del ser español». Las fuentes para esta historia serán la Literatura y el Arte, porque «proporcionan al historiador no sólo los valores humanos de un pueblo y los más originales (...) sino también los elementos constitutivos de su peculiar carácter" ${ }^{92}$.

El término Völkerpsycbologie se acuñó en Alemania en 1851 por Heymann Steinthal y surgió, precisamente, «como aplicación a la unidad colectiva 'pueblo' de los métodos de la psicología naturalistan" ${ }^{93}$. Este concepto impregna toda la teoría de la Historia del krausopositivismo y de la generación del 98, singularmente de Unamuno, Ganivet y Menéndez Pidal (ya veremos lo que pasa con Altamira). Aniano Peña nos refiere las diferencias entre Völkerpsychologie y Volksgeist: «en cuanto al origen, en cuanto al sentido y en cuanto a su visión y uso de la historian ${ }^{94}$. Pero independientemente de estas tres diferencias entre ambos conceptos, que dicho autor recoge de Ciriaco Morón Arroyo ${ }^{95}$, y de las puntualizaciones que pudiéramos deducir de ellas ${ }^{96}$, aquí resaltaríamos,

92 Todas estas citas de GómEz MOLLEDA, Ma Dolores: Los reformadores..., op. cit., de su capítulo titulado "La España de Giner", pp. 89-136.

93 Ver MORÓn ARROYO, Ciriaco: «La teoría crítica de Menéndez Pidals, op. cit., p. 26.

94 PeÑA, Aniano: «La 'Völkerpsychologie' y la visión de España en la Generación del 98», en Cuadernos Hispanoamericanos, $\mathrm{n}^{\circ} 331$, 1978, pp. 82-101: la cita en p. 84, nota 7.

9s a1. En cuanto al origen, la idea de Volksgeist es de origen especulativo y racionalista, en carabio, la Völkerpsychologie surge con signo naturalista en el sentido de un campo estudiable con procedimientos científico-natutales y en el sentido de un entaizamiento en el medio biológico. 2. El término Geist en alemán tiene un sentido mucho más objetivo que el español 'espíritu'; Geist es la cultura objetivada, no la potencia del hombre; de esta noción procede la supuesta divinización del 'espíritu del pueblo' como algo al margen del individuo, que actúa sobre éste. La psicología estudia el alma y sus potencias, es decir el individuo-sujeto; de ahí que Menéndez Pidal se oponga a todas las vaguedades de sujetos colectivos, y considere al individuo, auténticamente creador, no instrumento de la colectividad; sólo que ese individuo creador participa de la tradición fisiológica \{sic\} de esa colectividad y por eso comulga con sus ideales y caracteres. 3. La vinculación de la psicología de los pueblos a los elementos naturales, explica que el elemento conformador de las colectividades sea el pasado; en cambio el Volksgeist, precisamente porque se impone al individuo y en cierto sentido juega con él usándolo en su proceso de desarrollo, impone una visión futurista de la historian, en: Ciriaco MORÓN ARroYo: «La teoría crítica de Menéndez Pidal», op. cit., pp. 30ss.

${ }^{96}$ El término "fisiológica» alude a un concepto naturalista tan en boga como vimos en los finales del XIX, que no nos parece apropiado porque incide precisamente en una «vaguedad de sujeto colectivo» de la que expresamente estamos huyendo aquí, de todos modos el propio Morón Arroyo ya hace notar que sen la Völkerpsycbologie, como en todo el psicologismo del siglo XIX, había un elemento confuso: las relaciones entre medio, biología, psicología y biografían(p. 37); el punto 3 de la nota anterior deberíamos de matizarlo conforme a nuestras observaciones de más arriba acerca del 
sobre todo, dos distinciones entre Volksgeist y Völkerpsychologie que para este trabajo resultan particularmente relevantes: $1^{\text {a }}$ ) «Se presenta como característica de la crítica pidaliana el no haber dado gran importancia al elemento religioso de nuestra vida y literatura, tan puesto de relieve por Milá y Menéndez Pelayo» ${ }^{97} \mathrm{y}$, en cita de Ganivet: «La religión, con ser algo muy hondo, no es lo más hondo que hay en una nación: la religión cambia, mientras que el espíritu territorial subsiste»98: recordemos la importancia del providencialismo, con su carga de religión esencialista, en la visión de la historia del Volksgeist español, propio de la etapa del nacional-romanticismo que vimos en su momento; $y$, por otro lado, tengamos presente la heterodoxia que en lo religioso representa el krausismo; $2^{a}$ ) «La Völkerpsychologie acentúa más lo individual que el Volksgeist que tiene un sentido más objetivo" ${ }^{99}, \mathrm{y}$ ahora veamos cómo se explica esto: «si el concepto de Volksgeist podía producir la retórica del pueblo creador, la Völkerpsychologie no reconoce más autor que el individuo, individuo de cauce oculto, con raíces en su tierra e historia; él conoce a su pueblo y su pueblo le conoce a él; cuando el individuo compone, no tiene ninguna intención expresionista; canta aquello en que se siente inmerso y en que siente inmersos a sus oyentes ${ }^{100}$. La tesis que apoyo aquí es, en definitiva, que la Völkerpsychologie supone precisamente la versión liberal del Volksgeist: por su inmanentismo o, si se quiere, su desvinculación del Providencialismo que, al fin y al cabo, suponía la sacralización del espíritu del pueblo (recordar aquí el carácter religioso de los nacionalismos esencialistas ${ }^{101}$ ); y por su apelación al individualismo creador, donde no hay una entidad supraindividual que decida, son los individuos, anónimos si se quiere, pero reales, existentes, los protagonistas de una cultura, de una tradición. Ambos factores serían posibles precisamente en el ambiente restauracionista, cientifista que traerá consigo la positivación de los elementos que constituían ese Volksgeist peculiar español de toda la época romántica que vimos más arriba.

Rafael Altamira y Crevea (1866-1951) requiere un lugar aparte dentro del panorama de la Historiografía española, tanto por sus inquietudes teóricas como por las dimensiones de su obra historiográfica y hasta de su propia vida y que requeriría un tratamiento específico (del que ya se ocupan investigadores como Rafael Asín Vergara, entre otros). Altamira es autor, en unas circunstan-

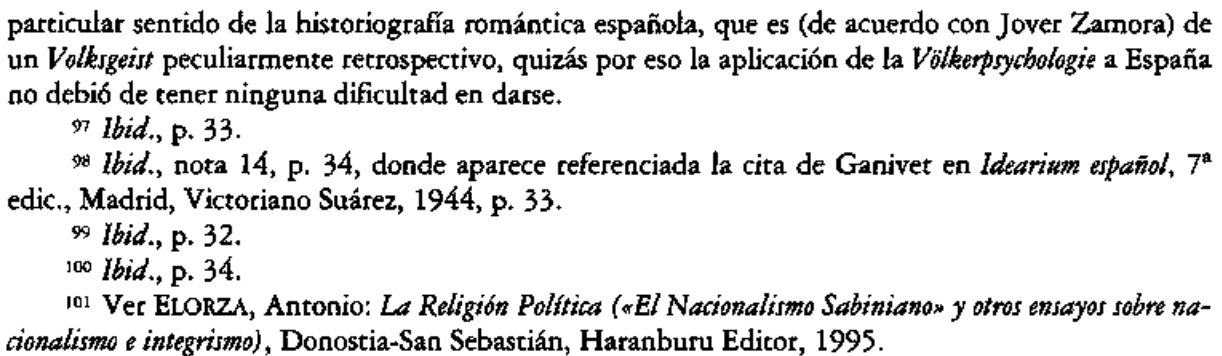


cias muy especiales relacionadas con el desastre del 98, de una Psicología del pueblo español (1902) y también de una muy posterior Los elementos de la civilización y del carácter de los españales (1950): ambas obras encajables en los supuestos iniciales de la historiografía "interna» del krausismo aunque ya con metodología positivista. No se trata en ellas de la Historia integral que él va persiguiendo, heredera directa de la Historia de la civilización liberal, que tampoco sería, según él, la de los imitadores españoles de Guizot ${ }^{102}$. Lo que Altamira viene a decir es que, si bien algunos historiadores del XIX ya saben cómo debe de ser la Historia integral, no ha habido en este siglo una obra en que dicho concepto se haga efectivo ${ }^{103}$. Este objetivo será, por tanto, el que persiga en su obra mayor ${ }^{104}$, Historia de España y de la civilización española (1900-1911, 4 vols.), donde aplica unos principios historiográficos —que, según él mismo, siempre defendió- reacios en todo momento a «una división de la historia humana [en historia interna o de la civilización e historia externa o política] contra la que vengo protestando desde que inicié, en 1891 , mis estudios de metodología» ${ }^{105}$. 1948:

102 Ver: Proceso Histórico de la Historiografía Humana, México, Fondo de Cultura Económica,

$\left.1^{\circ}\right)$ Sobre las carencias de este concepto de Historia de la Civilización, que no responde a su concepro de Hiszoria integral: "En pleno siglo XIX, dos errores vinieron (...) a impedir la adopción completa de la doctrina que muchos historiadores habían ya aceptado y practicado en sus libros. En primer término, la falsa aplicación de la palabra 'civilización' (...) a un escudio especial de lo que se llamaba tambièn 'historia interna', pero limirada a las instituciones políticas y algo de la organización social. Asi la entendió Guizoc en sus cursos de 1828-1830. El efecto fué que, durante algún tiempo, se creyó que en eso podía detenerse toda la novedad de la historiografía, con lo que se retrocedía al viejo sentido de la historia polírica. El otro error consistió en romper el sentido orgánico de la Historia separándola de la civilización y de la politica. Fué esta separación un producto de los que se oponían a la victoria del nuevo concepro íntegro (...). En consecuencia, unos historiadores querían mantener el exclusivismo; otros, la preponderancia de la historia política a que se subordinaba la no política, llamada unas veces interna y otras de la civilización. (...) En reacción a esas negaciones, se acentuó la importancia del otro elemento y se escribieron 'Historias de la civilización' que sistemáticamente excluían la historia política clásica.» (lbid., pp. 116-117).

$\left.2^{\circ}\right)$ Acerca de los juicios que sobre Tapia y Morón realiza Rafael Altamira, en íbid., pp. 111-112.

103 Ver Altamira, Rafael: Cuestiones modemas de bistoria, Madrid, Daniel Jorro editor, 1904: "Pero si este nuevo concepto del contenido de la Historia es el legado que el siglo XIX entrega al siglo XX para que lo cumpla, no es menos cierto que no le da para ello ningún modelo que ímitar o que mejorar. Falta todavía el libro que realice prácticamente esa idea orgánica del proceso histórico» (pp. 13-14).

ioi A pesar de que Ignacio Perró nos recuerda que el propio Alcamira la concibió como umanual para la segunda enseñanzas (Ver Los guardianes de la bistoria, op. cit. p. 168, nota 208).

ios Para la última cita: AlTAmIRA, Rafael: «Idea y estructura de una nueva Historia de la Civilización española» en Rafael Alcamira: Historia de la Civilización Española (edición de Rafael Asín Vergara), Barcelona, Crítica, 1988, pp. 43-44. Es lo que nos corrobora Jover ZAMORA, José Maria: La civilización española a mediados del siglo XIX, op. cit. p. 307: "Corresponde a Rafael Alramira el mérito de haber derribado, en el marco de la historiografia española, las barreras que tradicional- 
Estamos en el tránsito, ya señalado antes, del krausismo al krausopositivismo. Altamira, ya con el cambio de siglo, asimiló toda la metodología positivista que se practicaba en Europa ${ }^{106}$, con el precedente de otro krausista ilustre, Gumersindo de Azcárate ${ }^{107}$, aplicándola a la Historiografía y convirtiendo ésta en una disciplina plenamente moderna.

Es Altamira el primer historiador en el que las reflexiones que se vienen destilando en este trabajo hayan un eco comprensivo. Son artículos suyos como, por ejemplo, «Observaciones sobre el problema del genio y la colectividad en la historia» ${ }^{108}$ (además de otras de sus obras como La filosofía de la Historia y teoría de la civilización) donde la historiografía española empieza a entender que sin una comprensión de la Historia como pasado, esto es, sin una teorización de la Historia (=Filosofía de la Historia) y de la sociedad (=Sociología, incipiente entonces) no es posible fundamentar una Historia como relato. Es por la predisposición de Altamira hacia problemáticas teóricas de este tipo por lo que calificamos de auténtica oportunidad perdida para la Historiografía española, y para una necesaria Teoría de la Historia, el hecho de que no cuajara una relación intelectual estable entre él y Ortega, propicio como fué para ello el paso de éste último por el Centro de Estudios Históricos, pero ya vimos en la cita que abría este trabajo la consideración de Ortega hacia los historiadores. Altamira, además, es consciente de las repercusiones de su trabajo historiográfico en la conformación del espíritu nacional y las asume intentando siempre perfeccionarlas (es el tema de su discurso de ingreso en la Real Academia de la Historia: Valor social del conocimiento bistórico), situándose así en las antípodas del concepto subsidiatio y exclusivamente erudito de historiador que vimos con Menéndez Pelayo.

En el artículo arriba citado Altamira destila, entre otras afirmaciones, la siguiente: «Tratándose de actividad social, existe una afirmación común, de la cual deben partir todas las doctrinas, a saber: que la persona social no puede obrar sino por representación, que forzosamente recae en los individuos, y en este sentido cabe decir que 'la historia se compone de actos ejecutados por individuos'» ${ }^{109}$. Lo que se ha intentado demostrar en este trabajo es que un concepto así, o de cualquier otro cariz, de Historia como pasado y de individuo inserto en ella repercute necesariamente, se sea o no consciente de ello, en el concepto de sujeto como historiador y de Historia, como relato de ese pasado, que elabore. Que el historiador se responsabilice de esa relación y teorice sobre

\footnotetext{
mente venían separando la "historia interna' de la 'historia externa'». Y, en general, para entender el significado de Altamira, imprescindible: Armando Alberola (edit.): Estudios sobre Rafael Alsamira, Alicante, Diputación Provincial, Caja de Ahorros Provincial, 1987.

106 Ver Carreras ARES, Juan José: «Altamira y la historiografía europea», en Armando Alberola (edit.): Estudios sobre Rafael Altomira, op. cit., pp. 395-413.

${ }^{107}$ Del que ya hemos citado sus dos discursos teóricos fundarnentales en relación con la Historia.

108 En Boletín de la Institución Libre de Enseñanza, XXII, 1898, pp. 216-224.

los lbid., p. 221.
} 
ella es un requisito imprescindible para que la Historia deje de ser subsidiatia de otras disciplinas humanísticas y, al mismo tiempo, abra una puerta, sin prejuicios ni complejos, a la interdisciplinariedad. Se trata de una exigencia del momento historiográfico en que vivimos y que ya anticipó Rafael Altamira. 